Article

\title{
The Figure of Pontius Pilate in Josephus Compared with Philo and the Gospel of John
}

\author{
Christian Gers-Uphaus \\ Department of Theology, University of Notre Dame, Notre Dame, IN 46556, USA; cgersuph@nd.edu
}

Received: 6 December 2019; Accepted: 13 January 2020; Published: 30 January 2020

\begin{abstract}
In this paper, I attempt an approach to the 'historical Pilate.' I aim to present the sources referring to him as well as to point out their rhetorical tendencies. However, the approach is selective: whereas all references to Pilate in Philo and Josephus will be addressed, with respect to the New Testament, this study will be based only on the Gospel of John, because its text offers the longest narrative of the Roman trial of Jesus among the Gospels. At the end of each section, the main conclusions are presented. Finally, after discussed all the sources chosen for this work, I will try to depict a picture of the 'historical Pilate.'
\end{abstract}

Keywords: Pontius Pilate; Flavius Josephus; Philo of Alexandria; Gospel of John

\section{Introduction}

Pontius Pilate's time in office as the fifth governor of the Roman province of Judea was from 26 to 36 or 37 C.E. ${ }^{1}$ Judean Jews were situated in the center of Pilate's province and the Idumaean Jews in the south. Jerusalem was regarded by both groups as their religious and cultural center. Furthermore, to the north, were the Samaritans with Mount Gerizim as their religious center. Under the Roman governors, there were two cities of Judea considered as the capital: Jerusalem as the traditional one and the focus of Jewish religious life and Caesarea as the residence of the Roman governor together with his troops and family. Occasionally, especially during festivals, the governor moved to Jerusalem. His responsibilities were primarily military, which is shown also by his title 'prefect' (ह̌ $\pi \alpha \rho \chi 0 \varsigma){ }^{2}$

The fact that Jesus of Nazareth was crucified under his rule makes Pilate an important figure for the New Testament, Christian creeds, ${ }^{3}$ post-canonical literature, ${ }^{4}$ and also in popular imagination. Inextricably linked with Pilate are 1) the image of his handwashing in order to avoid responsibility and 2) his question, 'Quid est veritas?' (John 18:38). ${ }^{5}$ Apart from his own person, the New Testament bears only one reference to his wife warning him against a judgement on Jesus (Matt 27:19). ${ }^{6}$ Two contemporary nonbiblical sources, which both refer to Pilate, are the Jewish writers Philo and Josephus.

In the present work, I attempt an approach to the 'historical Pilate.' I aim to present the sources referring to him as well as to point out their rhetorical tendencies. The approach is selective: whereas all references to Pilate in Philo and Josephus will be addressed, with respect to the New Testament,

1 See for example (Lémonon 2007, p. 263). For a critical discussion on this, see (Krieger 1992, pp. 27-32) and (Blinzler 1969, pp. 271-3).

2 Under Claudius (41-54 C.E.), the title was changed to 'procurator' (' $\varepsilon \pi i \tau \rho \pi$ s $\varsigma$ ). The title 'prefect,' although not testified by Josephus, Philo, or Tacitus, is also confirmed by an inscription found in Caesarea in 1961. See for example (Lémonon 2007, pp. 23-31).

3 See (Staats 1987).

4 See (Diebner 2002).

5 See (Bond 1998, p. xi).

6 For a study on her, see (Kany 1995). 
this study will be based only on the Gospel of John, because its text offers the longest narrative of the Roman trial of Jesus among the Gospels. At the end of each section, the main conclusions are presented. Finally, after having discussed all the sources chosen for this work, I will try to depict a picture of the 'historical Pilate.'

\section{Pilate in Philo}

The earliest literary reference to Pilate can be found in Philo's work Embassy to Gaius (Legatio ad Gaium) in paragraphs 299 and 304.7 The part that is of interest to us is the following:

(299) I [sc. Agrippa I] can also tell you of something on which he prided himself, although I experienced countless sufferings during his lifetime. But you love and respect the truth. Pilate was an official who had been appointed procurator of Judaea. With the intention of annoying the Jews rather than of honouring Tiberius, he set up gilded shields in Herod's palace in the Holy City. They bore no figure and nothing else that was forbidden, but only the briefest possible inscription, which stated two things - the name of the dedicator and that of the person in whose honour the dedication was made. (300) But when the Jews at large learnt of his action, which was indeed already widely known, they chose as their spokesmen the king's four sons, who enjoyed prestige and rank equal to that of kings, his other descendants, and their own officials, and besought Pilate to undo his innovation in the shape of the shields, and not to violate their native customs, which had hitherto been invariably preserved inviolate by kings and emperors alike. (301) When Pilate, who was a man of inflexible, stubborn and cruel disposition, obstinately refused, they shouted, 'Do not cause a revolt! Do not cause a war! Do not break the peace! Disrespect done to our ancient Laws brings no honour to the Emperor. Do not make Tiberius an excuse for insulting our nation. He does not want any of our traditions done away with. If you say that he does, show us some decree or letter or something of the sort, so that we may cease troubling you and appeal to our master by means of an embassy.' (302) This last remark exasperated Pilate most of all, for he was afraid that if they really sent an embassy, they would bring accusations against the rest of his administration as well, specifying in detail his venality, his violence, his thefts, his assaults, his abusive behaviour, his frequent executions of untried prisoners, and his endless savage ferocity. (303) So, as he was a spiteful and angry person, he was in a serious dilemma; for he had neither the courage to remove what he had once set up, nor the desire to do anything which would please his subjects, but at the same time he was well aware of Tiberius' firmness on these matters. When the Jewish officials saw this, and realized that Pilate was regretting what he had done, although he did not wish to show it, they wrote a letter to Tiberius, pleading their case as forcibly as they could. (304) What words, what threats Tiberius uttered against Pilate when he read it! It would be superfluous to describe his anger, although he was not easily moved to anger, since his reaction speaks for itself. (305) For immediately, without even waiting until the next day, he wrote to Pilate, reproaching and rebuking him a thousand times for his new-fangled audacity and telling him to remove the shields at once and have them taken from the capital to the coastal city of Caesarea (the city named Sebaste after your great-grandfather), to be dedicated in the temple of Augustus. This was duly done. In this way both the honour of the Emperor and the traditional policy regarding Jerusalem were alike preserved. ${ }^{8}$

The incident described in the Embassy is found within a letter from Agrippa I to Emperor Gaius Caligula, trying to persuade him to respect the Jewish Law by referring to those preceding him and, therefore, to dissuade him from setting up his statue in the Jerusalem Temple. ${ }^{9}$ For fruitful work on the question of Pilate's character, we have to be aware of this literary composition. Thus, I will discuss, briefly, its circumstances and particularities in the following paragraphs. ${ }^{10}$

(Philo 1970, par. 299-305 [trans. Smallwood, pp. 128-31]).

See (Lémonon 2007, p. 189). The whole letter can be found in (Philo 1970, par. $276-329$ [trans. Smallwood, pp. 122-37]).

10 For a more detailed view on this see also (Smallwood 1976, pp. 220-55). 


\subsection{Historical Background of the Embassy}

The Embassy is an invective against Emperor Gaius, with episodes showing, according to Philo, his hostility toward the Jews. Philo refers to two attacks made on them during the governorship of Gaius: the anti-Jewish riots in Alexandria in the summer of 38 C.E. and Gaius' attempt to dedicate the Temple in Jerusalem to the imperial cult. ${ }^{11}$

Although the city of Alexandria was dominated by Greek citizens, its Jewish Diaspora community was a large one and needed some definite organization beyond its division into synagogues. In fact, the Jews in Alexandria "were constituted as a quasi-autonomous civic unit, generally known as a $\pi 0 \lambda i \tau \varepsilon v \mu \alpha$ by modern, if not always by ancient, writers." 12 From the time of Ptolemy I, the Jews had the right of residence in Alexandria, but, concerning their status of citizenship, they occupied only an intermediate position between the Greek citizens and the Egyptians who were totally without privileges. Having coexisted peacefully during the time of Ptolemaic dominance, hostility began with the annexation of Egypt in 30 B.C.E. by the Romans, but it did not take an active form for over sixty years. It seems that this hostility had its roots primarily in the complications introduced into the Alexandrian situation by the Roman annexation and, originally, was not based on hatred against Jews in general. ${ }^{13}$ By the 30s C.E., after a party of Greek nationalists had arisen in Alexandria, the passive hostility changed into a brutal anti-Semitism and finally culminated in the riots against the Jews, which followed the visit of Agrippa I to Alexandria in August 38 C.E. First, a mob gathered in the gymnasium brought out a succession of gibes against the king. ${ }^{14}$ Because this went unpunished by the prefect Flaccus, the Greeks mocked him by dressing up a certain lunatic named Carabas as a king. ${ }^{15}$ Furthermore, being aware of the prefect's impotence, the Greek mob deprived the Jews of the use of their synagogues. ${ }^{16}$ It was not until Flaccus' sudden arrest by soldiers arriving from Rome in the autumn of 38 C.E. that conditions returned to normal for the Alexandrian Jews. ${ }^{17}$

As a consequence of these troubles, "three delegates were chosen by each of the factions and appeared before Gaius." 18 While waiting to be received by the emperor in order to defend the interests of the Alexandrian Jews in light of their maltreatment by the Greeks, the Jewish embassy learned that Gaius had ordered that a statue be set up and named after Zeus in the Jerusalem Temple. ${ }^{19}$ Finally, after being heard by him twice, Gaius left them within, saying: "I think that these men are not so much criminals as lunatics in not believing that I have been given a divine nature." ${ }^{20}$

In summary, the embassy to Gaius was not successful. Philo himself says so clearly.21 Thus, I may ask the question: for what purpose did Philo publish his Embassy to Gaius?

11 See Smallwood, Introduction to (Philo 1970, p. 3).

12 (Smallwood 1976, p. 225). A further discussion on this terminus technicus will not be done here. For this, see also (Smallwood 1976, pp. 225-35).

13 See (Smallwood 1976, p. 233). According to her, the trouble probably arose over the question of the civic position of the Jews. See (Smallwood 1976, p. 234).

14 (Philo 1960, par. 32-4 [trans. Colson, pp. 318-21]).

15 (Philo 1960, par. 36-9 [trans. Colson, pp. 322-5]).

16 (Philo 1960, par. 41-53 [trans. Colson, pp. 324-33]).

17 (Philo 1960, par. 102-24 [trans. Colson, pp. 358-71]). According to Philo, Emperor Gaius decided on it after having received a letter from Agrippa I from Alexandria explaining Flaccus' suppression. For a further discussion on this letter, see the following paragraph.

18 (Josephus 1965, XVIII, par. 257 [trans. Feldmann, pp. 152-3]). This voyage to Rome probably took place in the winter of 39-40 C.E.

19 See (Philo 1970, par. 187-9 [trans. Smallwood, pp. 100-1]).

20 (Philo 1970, par. 367 [trans. Smallwood, pp. 144-5]). The two audiences given to them are told in (Philo 1970, par. 349-67 [trans. Smallwood, pp. 140-5]). Josephus mentions only the second hearing in (Josephus 1965, XVIII, par. 257-60 [trans. Feldmann, pp. 152-5]). For a more detailed study on this part, see (Smallwood 1976, pp. 242$5)$.

21 See (Philo 1970, par. 368-73 [trans. Smallwood, pp. 144-7]). 


\subsection{The Letter of Agrippa-Considerations on Philo's Political Rhetoric}

In order to find a reliable answer to this, we should keep in mind that the Embassy was written after Gaius' death in 41 C.E., 22 probably in the early part of Claudius' reign, in order "to persuade the new Emperor [sc. Claudius] not to follow the policies of Gaius but those of his predecessors, Augustus and Tiberius, ${ }^{\prime 23}$ because this is relevant to his success as emperor. On a higher level, the whole work contains a scheme similar to this. Furthermore, Philo's so-called historical writings, comprising the Embassy and the Flaccus, are marked by rhetorical and theological concerns. ${ }^{24}$ In particular, this is prominent in his treatment of the characters and actions of Roman Emperors and officials, leading us back to our subject, Pilate.

Agrippa's letter to Gaius in the Embassy includes the only reference to Pilate in Philo's works. However, is it really a work of Agrippa himself? First of all, from a stylistic point of view, the letter fits with Philo's text of the whole Embassy. Secondly, ancient literature offers examples of discourses that were not delivered by those to whom they were dedicated. ${ }^{25}$ Despite these reservations concerning an Agrippian authorship of this letter presented in the Embassy, the possible existence of a real letter from him in that conflicting situation cannot be totally rejected; ${ }^{26}$ however, whether the historical Agrippa wrote one is unknown to us. ${ }^{27}$ Certainly, the one in the Embassy is a Philonian composition. ${ }^{28}$

In the Embassy (and also in the Flaccus), Philo makes use of several rhetorical themes, which I will take briefly into consideration with regard to the relevant passage cited above:29

(1) He stresses that the Jews are loyal and peaceful members of the Roman Empire, striving for "respect for the Emperor" as well as "obedience to [their] hallowed laws."30 They show respect to their emperor, but they cannot tolerate any disrespect toward their own laws. The incident of the Gilded Shields shows that "there is no fundamental conflict between these two positions," 31 because by removing them, "both the honour of the Emperor and the traditional policy regarding Jerusalem were alike preserved." 32 According to Philo, it is obvious that dishonor shown toward Jewish Law is therefore connected with dishonor to the emperor, ${ }^{33}$

22 The Embassy mentions events after Gaius' time as Roman Emperor. See (Philo 1970, par. 206 [trans. Smallwood, pp. 106-7]).

23 (Bond 1998, p. 33). For this view, see also (Lémonon 2007, pp. 190-1). That is why (Schwartz 1983, p. 32) speaks correctly of a "context that is doubly apologetic, reflecting Agrippa's situation in relation to Caligula, and Philo's in relation to Claudius."

24 See also (Bond 1998, p. 25). See also (Thatcher 1995, p. 218): “Legatio may be 'history,' but it is history in service of a rhetorical agenda."

25 See (Lémonon 2007, p. 191), particularly fn. 17. For an ongoing study on this see also the works of (Stowers 1986) and (Malherbe 1986).

26 See (Lémonon 2007, p. 191): “Ces réserves étant faites, on ne peut pas refuser l'existence d'une lettre du roi Agrippa à Gaius dans les circonstances dramatiques narrées par Philo."

27 For an ongoing discussion on this, see (Zeitlin 1965, pp. 22-31).

28 See (Thatcher 1995, p. 216) and Smallwood, Commentary on (Philo 1970, par. 276, pp. 291-2). This conclusion will be sufficient for our further considerations on Pilate. Furthermore, Lémonon mentions in his work threeconvincing-reasons for the supposition that Philo probably appears to be inspired by thoughts that were originally related to Agrippa. For this see (Lémonon 2007, pp. 191-2). However, Josephus does not know of such a letter. He speaks of Agrippa's appeal to Gaius in the context of a banquet in Rome. See (Josephus 1965, XVIII, par. 289-97 [trans. Feldmann, pp. 168-73]). See also the summary of (Zeitlin 1965, p. 31): “The letter of Agrippa to Gaius, as recorded by Philo, was composed by Philo in accordance with his theology. The speech of Agrippa to Gaius, as recorded by Josephus, was composed by Josephus in the spirit of the historiography of the Greeks."

29 See also (Bond 1998, pp. 33-6).

30 (Philo 1970, par. 236 [trans. Smallwood, pp. 114-5]).

31 (Bond 1998, p. 34).

32 (Philo 1970, par. 305 [trans. Smallwood, pp. 130-1]).

33 See (Philo 1970, par. 301 [trans. Smallwood, pp. 128-9]). 
which is recognized immediately by an emperor such as Tiberius. ${ }^{34}$ Therefore, Pilate's action of setting up the shields can only have been "with the intention of annoying the Jews rather than of honouring Tiberius." 35

(2) As already mentioned above, concerning Philo's motivation for publishing the Embassy, he tries to persuade Claudius not to follow the policy of Gaius with regard to the Jews, but rather those policies of Augustus ${ }^{36}$ and Tiberius ${ }^{37}$, described by Philo as men of high moral standing, showing respect and honour toward Jewish Law and traditions and whose long reigns were peaceful and prosperous. Contrary to those is the depiction of Gaius ${ }^{38}$ as an enemy of the Jews.

(3) The fate of Flaccus, being removed from office, shows in Philo's works what happens to an official acting against Jewish Law. ${ }^{39}$ Furthermore, the Embassy includes references to a greater number of Jews in the empire who would certainly rise up in the case of offense to their religion. ${ }^{40}$ The warnings of the spokesmen reproduced by Philo ${ }^{41}$ fit with this theme and, therefore, give a clear indication that such an action - such as the one involving the shields by Pilate-could be followed by a revolt throughout all the empire. ${ }^{42}$

Having analyzed these rhetorical tendencies in Philo's Embassy (and in the Flaccus), I will now take into consideration how Pilate is presented to us in the incident of the Gilded Shields. Philo's political rhetoric enhances his theology and vice versa, and both aspects influence his portrayal of Pilate. ${ }^{43}$ Keeping this in mind, I will attempt to provide some concluding remarks on the 'historical Pilate' in the last paragraph of this section.

\subsection{Philo's Presentation of Pilate in the Incident of the Gilded Shields}

With regard to Embassy 299-305, Philo's depiction of Pilate conforms to the picture of a Roman official disrespecting the Jews and their law. ${ }^{44} \mathrm{He}$ is described as intending to annoy the Jews

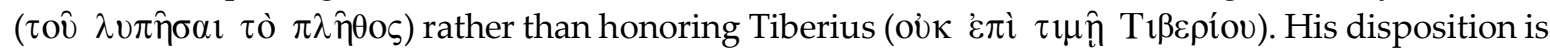

See (Philo 1970, par. 304-5 [trans. Smallwood, pp. 130-1]).

(Philo 1970, par. 299 [trans. Smallwood, pp. 128-9]).

36 For Augustus, see for example: (i) (Philo 1960, par. 74 [trans. Colson, pp. 342-3]): "savior and benefactor" or (ii) (Philo 1970, par. 143 [trans. Smallwood, pp. 90-1]): “What about the Emperor whose every virtue outshone human nature, who through the greatness of his imperial rule and of his valour alike became the first to bear the name 'Augustus,' who did not receive the title by inheritance from his family as part of a legacy, but was himself the source of the reverence paid to his successors also?" or (iii) (Philo 1970, par. 309 [trans. Smallwood, pp. 1301]): "Now what about your great-grandfather, the best of all the Emperors who have ever lived, who was the first to be called Augustus because of his goodness and position, and who spread peace everywhere by land and sea to the ends of the earth?"

37 For Tiberius, see for example: (i) (Philo 1970, par. 141 [trans. Smallwood, pp. 88-9]): “He [sc. Tiberius] held sway over land and sea for twenty-three years without allowing any spark of war to smoulder in Greek or barbarian lands, and he gave peace and the blessings of peace to the end of his life with ungrudging bounty of hand and heart." or (ii) (Philo 1970, par. 298 [trans. Smallwood, pp. 128-9]): “Then what about your other grandfather, Tiberius Caesar? Was his policy not clearly the same? At any rate, during the twenty-three years of his principate he safeguarded the Temple ritual which had been handed down from the distant past, and did not abolish or disturb a single item of it."

38 For Gaius, see for example: (Philo 1970, par. 77; 133; 162; 201 [trans. Smallwood, pp. 72-3; 86-7; 94-5; 104-5]): "blasphemous deification of himself;" "felt an indescribable hatred for the Jews;" "swelled with pride;" "how hostile he was towards the whole Jewish race."

39 See (Philo 1960, par. 116 [trans. Colson, pp. 366-7]): “It [sc. Flaccus' arrest] was caused, I [sc. Philo] am convinced, by his treatment of the Jews, whom in his craving for aggrandisement he had resolved to exterminate utterly."

40 See for example the issue of Gaius' plan of erecting a statue in Jerusalem in (Philo 1970, par. 217 [trans. Smallwood, pp. 108-11]): "So he [sc. Gaius] was naturally very much afraid that, when these Jews heard of the proposed new dedication, they would suddenly invade and encircle him, some from one side and some from the other, and then join forces and maltreat those whom they had surrounded."

41 See (Philo 1970, par. 301 [trans. Smallwood, pp. 128-9]). This passage has already been cited above.

42 Regarding Philo's rhetorical aims - and the relative smallness of Pilate's offense - these warnings have probably been exaggerated. See also (Bond 1998, pp. 33-5).

43 See (Bond 1998, p. 26).

44 For the following analysis, see also (Bond 1998, pp. 31-3). 


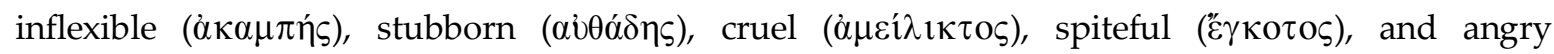
( $\beta \alpha \rho u ́ \mu \eta v i \varsigma)$, without having the courage to do anything to please his subjects. ${ }^{45}$ Concerning his

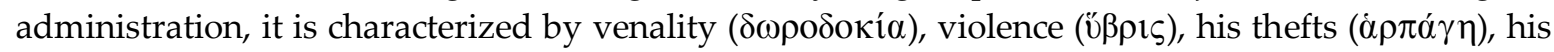

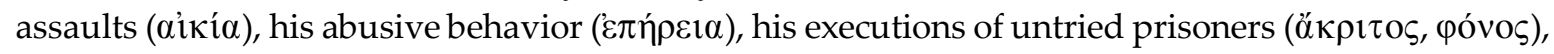
and his savage ferocity $(\hat{\alpha} \rho \gamma \alpha \lambda \varepsilon \dot{\varepsilon} \sigma$, o $\mu$ ó $\tau \eta \varsigma)$. In order to get nearer to the 'real Pilate,' we have to answer the question of whether these adjectives are used in Philo's historical writings (the Embassy and the Flaccus) exclusively to describe him or if there are indications for a common use. ${ }^{46}$

First of all, none of these adjectives are used only for Pilate. The charge of annoying the Jews rather than honoring the emperor is also an accusation against the Alexandrian mob. ${ }^{47}$ The word $\dot{\alpha} \kappa \alpha \mu \pi \eta \varsigma_{\varsigma}$ is also used for captors allowing their captives to go for money, not mercy;8 $\alpha \dot{v} \theta \alpha \dot{\alpha} \delta \eta \varsigma$ describes the evil speech of the Alexandrians; ${ }^{49}$ and $\dot{\alpha} \mu \varepsilon i \lambda \imath 1 \kappa \tau o \varsigma$ is referred to two times in order to describe the character of Gaius.50 Parallels to the description of Pilate's administration can also be found as follows: $\delta \omega \rho о \delta$ кía is used to describe the bribes given to Flaccus' accusers by Isodorus; ${ }^{51}$

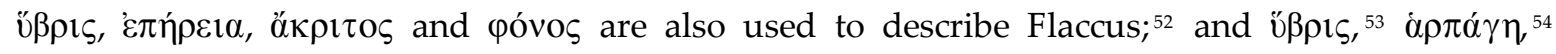

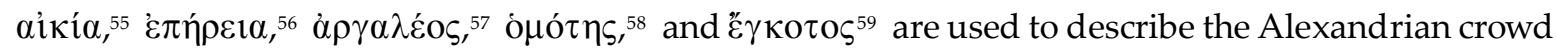

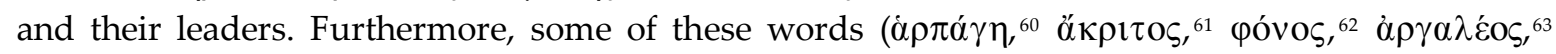

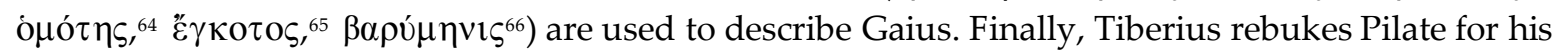

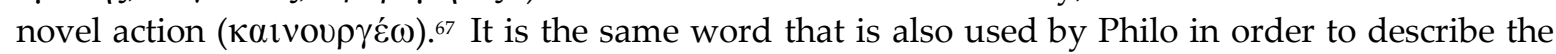
cruelty of the Alexandrian mob, ${ }^{68}$ Gaius' statue, ${ }^{69}$ and his acts of megalomania..70

To sum up, Philo's presentation of Pilate is not based on a personalized attack but, rather, on general terms that are used by him regularly to describe those who do not respect the Jews, in particular Gaius and the Alexandrians. ${ }^{71}$ Moreover, our conclusion is supported by a passage from the Flaccus, giving a general description of a corrupt governor. The text, which refers even in Greek to some of the keywords analyzed above, is as follows:

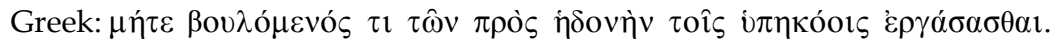

4 This question is also posed by Bond and McGing. See (Bond 1998, p. 31) and (McGing 1991, p. 433).

47 See (Philo 1960, par. 51 [trans. Colson, pp. 332-3]).

48 See (Philo 1960, par. 60 [trans. Colson, pp. 336-7]).

4 See (Philo 1960, par. 35 [trans. Colson, pp. 320-1]).

See (Philo 1960, par. 182 [trans. Colson, pp. 398-9]) and (Philo 1970, par. 350 [trans. Smallwood, pp. 140-1]).

1 See (Philo 1960, par. 140 [trans. Colson, pp. 378-9]).

2 See (Philo 1960, par. 173; 103; 54; 189 [trans. Colson, pp. 394-5; 358-9; 332-3; 402-3]).

3 See (Philo 1960, par. 40; 59; 95; 136 [trans. Colson, pp. 324-5; 334-5; 354-5; 376-7]).

54 See (Philo 1960, par. 56-7; 62; 69 [trans. Colson, pp. 334-5; 336-7; 340-1]) and (Philo 1970, par. 122; 129 [trans. Smallwood, pp. 84-5; 86-7]).

55 See (Philo 1960, par. 59; 71-2; 96 [trans. Colson, pp. 34-5; 340-1; 354-7]) and (Philo 1970, par. 128 [trans. Smallwood, pp. 84-7]).

56 See (Philo 1970, par. 134 [trans. Smallwood, pp. 86-9]).

57 See (Philo 1960, par. 21; 95 [trans. Colson, pp. 314-5; 354-5]).

58 See (Philo 1960, par. 59; 66 [trans. Colson, pp. 334-7; 338-9]).

59 See (Philo 1960, par. 19 [trans. Colson, pp. 312-3]).

See (Philo 1970, par. 105 [trans. Smallwood, pp. 78-81]).

1 See (Philo 1970, par. 344 [trans. Smallwood, pp. 138-9]).

62 See (Philo 1970, par. 66 [trans. Smallwood, pp. 70-1]).

See (Philo 1960, par. 182 [trans. Colson, pp. 398-9]).

See (Philo 1970, par. 341 [trans. Smallwood, pp. 138-9]).

See (Philo 1970, par. 260 [trans. Smallwood, pp. 120-1]).

See (Philo 1970, par. 260 [trans. Smallwood, pp. 120-1]).

See (Philo 1970, par. 305 [trans. Smallwood, pp. 130-1]).

See (Philo 1960, par. 59 [trans. Colson, pp. 334-5]).

See (Philo 1970, par. 217 [trans. Smallwood, pp. 108-9]).

See (Philo 1970, par. 348 [trans. Smallwood, pp. 140-1]).

See also (McGing 1991, p. 433) and (Bond 1998, p. 32). 
(105) Some, indeed, of those who held governorships in the time of Tiberius and his father Caesar, had perverted their office of guardian and protector into domination and tyranny and had spread

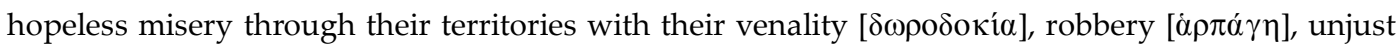
sentences, expulsion and banishment of quite innocent people, and execution of magnates without trial [ák $\rho \imath \tau$ ऽ)]. But these people on their return to Rome, after the termination of their time of office, had been required by the emperor to render an account and submit to scrutiny of their doings, particularly when the aggrieved cities sent ambassadors. ${ }^{72}$

Apart from these three identical words, the cited passage includes even a reference to an embassy that will inform the emperor about the misdeeds of the (corrupt) governor. ${ }^{73}$ Historically, Pilate may have appeared in the eyes of the Jews as an inflexible, stubborn, cruel, and violent governor. ${ }^{74}$ Because Pilate acted against Jewish Law-because he wanted to show loyalty to Tiberius - he is described by Philo "in precisely the same terms as other 'enemies' of the Jews: Gaius, Flaccus $[\ldots]$ and the Alexandrians, ${ }^{\prime 75}$ doubtlessly exaggerated according to his theological rhetoric. ${ }^{76}$ However, his action surely caused offense in some way and, therefore, is not only simply Philonian rhetoric. ${ }^{77}$ Thus, it should be possible to come to a plausible reconstruction of the historical event behind Embassy 299-305.

\subsection{Notes on the Historical Event}

The question to be answered is the following: Is the incident of the Gilded Shields an example of the hypersensitivity of the Jews, or in what way did the shields cause offense against Jewish Law? What was different about these shields ( $\alpha \sigma \sigma i ́ \delta \varepsilon \zeta)$ compared, for example, with those set up in the Alexandrian synagogues? ${ }^{78}$

According to Philo, the shields bore no figure ${ }^{79}$ and nothing else that was forbidden, ${ }^{80}$ except a brief inscription, ${ }^{81}$ revealing the name of the dedicator $(\dot{\alpha} v \alpha \theta \dot{\varepsilon} v \tau \alpha)$ and that of the person in whose

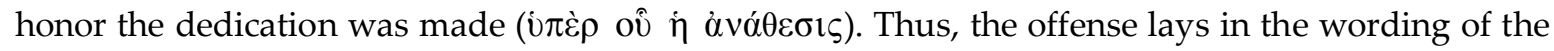
inscription. ${ }^{82}$ Otherwise, if there was not any offense, the whole incident would lose its significance, ${ }^{83}$ and Philo, with regard to his rhetorical aim, would have succeeded only in presenting Jewish

(Philo 1960, par. 105 [trans. Colson, pp. 360-1]).

And that can be regarded as a clear parallel to Pilate's fear in (Philo 1970, par. 302).

74 Not all characteristics concerning Pilate and his maladministration given by Philo are repeated here. For this, see the analysis above.

75 (Bond 1998, p. 33).

76 See also the statement in (Lémonon 2007, p. 204), concerning the 'review' on Pilate's administration in Embassy, par. 302: “Le texte présente une exagération évidente. La Judée n'aurait pas supporté dix ans un tel gouverneur, et les procuratuers dont les actions ont conduit à la révolte juive sont à peine accusés par Josèphe d'autant de méfaits." It should be noted that the description of Tiberius as benefactor of the Jews, and particularly his reaction toward Pilate's action, in Philo is simply exaggerated, or at least selective, because it does not mention, for example, the expulsion of the Jews from Rome in 19 C.E., which is noted in (Josephus 1965, XVIII, par. 79-83 [trans. Feldmann, pp. 56-61]). For further considerations on this, see (Lémonon 2007, pp. 200-2).

77 This is shared by (Thatcher 1995, p. 218). Furthermore, according to (Bond 1998, p. 37), Philo was probably in possession of some accurate facts, because he was a friend of Agrippa I. See also the statement of (Mason 2005, p. 168): "Nevertheless, where there is smoke there may be fire."

78 See (Philo 1970, par. 133 [trans. Smallwood, pp. 86-7]). The Greek reference is also ḋo $\pi \dot{\delta} \delta \varepsilon \varsigma$.

79 Usually, à $\sigma \pi i$ i bore an image of a god or a great man. It corresponds to the Latin clipeus. See (Lémonon 2007, pp. 196-7).

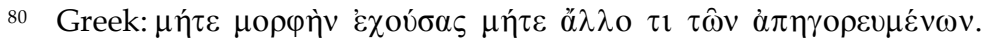

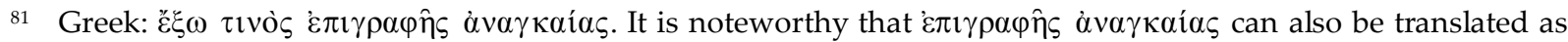
"necessary inscription." This translation is also proposed by (Davies 1986, p. 110): "[...] the word 'necessary' seems to make fully sufficient sense as a translation."

82 Now, the difference to those put up in the Alexandrian synagogues becomes clear. Moreover, those were put up by the Jews themselves!

83 (Lémonon 2007, p. 197) and (Bond 1998, p. 38) also make this point. 
hypersensitivity and not, as already shown above, in showing how offense caused by a Roman official against Jewish Law is reprimanded.

Pilate probably referred to himself in the same way as in the inscription found in Caesarea in 1961, possibly adding his title. Thus, the full reference would have been: 'Pontius Pilatus. Praefectus Iudaeae. ${ }^{84}$ Because neither of these words seems to offend Jewish Law, scholars agree that the offense must have been in the name of Tiberius, referring to him by a phrase that included his designation as filius divi Augusti. ${ }^{85}$ Finally, with respect to the context of the Agrippian letter, we should also consider the observation made by Lémonon that, possibly, with regard to Embassy 306, "Philon minimise les motifs de l'incident pour mieux mettre en valeur le scandale provoqué par l'érection de la statue de Caligula dans l'adyton, véritable provocation à l'égard des Juifs." ${ }^{86}$ However, although this cannot be proved sufficiently because Philo is our only reference for this incident, ${ }^{87}$ there remains the fact of the offending inscription. 88

Concerning the question on the date of the incident, it seems to be the most probable solution that it occurred at a Jewish feast, because this is the most likely explanation for the simultaneous presence of the King's four sons and Pilate in Jerusalem. According to major scholarship, the terminus a quo for the incident seems to be the end of 31 C.E. after the assassination of L. Aelius Sejanus, the powerful commander of the Praetorian Guard who had a hatred for the Jews. The politically unstable conditions after his death allowed Pilate to demonstrate loyalty to the emperor by putting up the Gilded Shields. ${ }^{89}$

\subsection{Conclusions - Pilate's Picture in Philo}

Pilate is presented to us by Philo as a governor who wants to annoy the Jews by an unprecedented erection of shields bearing a forbidden inscription in Jerusalem. His description of Pilate's character ${ }^{90}$ and government ${ }^{91}$ fits with his description of other figures within the Embassy and the Flaccus disrespecting the Laws of the Jews, particularly Gaius, the Alexandrian mob, and the socalled 'corrupt governor' in Flaccus 105. This negative description is based on his rhetorical aim, which is to convince Claudius not to follow the policy of Gaius, and on his theology, which depicts enemies of the Jews as the enemies of God and thus in an extremely negative way. ${ }^{92}$

For the inscription, see also the remarks made in the Introduction.

85 Ser

See (Lémonon 2007, p. 197), (Bond 1998, pp. 38-9), (Schwartz 1983, p. 431), and (Fuks 1982, p. 507). For an ongoing check of dedications for or of Tiberius, see also ILS 113; 114; 152; 153; 155; 156; 159; 160; 164; 5818; 5829; 5829a; 6080 .

86 (Lémonon 2007, p. 197). This is also shared by (Schwartz 1983, p. 33): "If the Jews protected such innocent objects, how much more would they resist the erection of a statue (§ 306)!" See also (Krieger 1995, p. 76): “In diesem Zusammenhang [des Briefes; CGU] dient die Pilatus-Episode dazu, in LegGai 306 eine conclusio a minore ad maius ziehen zu können."

87 It should be noted that there is a wide discussion on the question of whether Josephus (1927, II, par. 169-74 and (1965, XVIII, par. 55-9) and Philo refer to the same incident or not. See (Schwartz 1983, pp. 26-45) who also gives chronological lists of works claiming either for a one-incident opinion or not. See also (Lémonon 2007, p. 206), and, for a more detailed discussion, (Maier 1969, pp. 109-21). For a brief comparison of both versions, see also (Krieger 1994, pp. 42-3).

88 Further considerations could be made here but are omitted. Undoubtedly, there was an offense, and the-very subtle-question to be answered is whether the offense derived from the inscription itself (as concluded in this paper and seen by [Bond 1998, p. 41] and [Fuks 1982, p. 507]) or from the dedication, i.e., from the facts that the inscription revealed (shared by [Lémonon 2007, p. 195] and [Davies 1986, pp. 112-3]). These scholars see strong arguments in favor of a religious interpretation of the Greek àvó日 $\theta \varepsilon \sigma 1 \zeta$.

89 See (Bond 1998, p. 44; Maier 1969, pp. 113-4; Fuks 1982, pp. 504-5; McGing 1991, p. 425). Because (Philo 1970, par. 159-61 [trans. Smallwood, pp. 94-5]) and (Philo 1960, par. 1 [trans. Colson, pp. 302-3]) is the only source for Sejanus' anti-Semitic sentiments, this theory has been criticized by (Schwartz 1983, pp. 35-7) and (Krieger 1995, p. 78).

90 As spiteful, angry, etc. See above.

91 Showing his venality, violence, etc. See above.

92 See (Bond 1998, p. 47). 
Nevertheless, the historical Pilate has become visible as a Roman governor who wants to be loyal to his emperor, in particular during troubled times after the death of Sejanus. He fears to remove the shields, because this would show dishonor to the emperor and negate the whole project. This seems to have been his main priority rather than an attempt to please his people. Therefore, his erection of the Gilded Shields was not an intentional act of aggression as Philo suggests. Perhaps, he thought that his action was less offensive, because the shields did not bear images as usual and were put up in an appropriate place in the Herodian palace. However, nevertheless, there remains the reproach of insensitivity toward Jewish traditions: after having already been in office for some years, Pilate must have been aware of the offensiveness of Tiberius' full title, in particular, while referring to him on shields, which were probably introduced to Jerusalem at a Jewish feast.

\section{Pilate in Josephus}

Josephus refers to Pilate in his two major works: the Jewish War (II 169-75) and the Jewish Antiquities (XVIII 55-89)93. Although both books were written under Flavian patronage and he himself was born after Pilate's time in office in Judaea, ${ }^{94}$ his description probably relies on information from his parents and grandparents. Theological and rhetorical aims - similar to those in Philo's work - can also be found in his works, and therefore, we have to be aware of particularities in his literary style. ${ }^{95}$ The War, written between 75 and 79 C.E., contains two incidents regarding Pilate; and the Antiquities, finished around 93 C.E., add two more. ${ }^{96}$

\subsection{Pilate in the Jewish War ${ }^{97}$}

In the War, we are told about two incidents that took place between Pilate and the Jewish people: the conflict over the images of the emperor (II 169-74) and the trouble caused by the erection of an aqueduct (II 175-77). Before dealing with the two reports themselves, I will-briefly-consider their context within the second book and some of the aims of the War. ${ }^{98}$

The beginning of War II deals with a description of the disturbances after the death of King Herod (II 1-79), which is followed by accounts on the division of the country between his sons, Archelaus' short reign, the transformation of Judea into a Roman province under Augustus, and the revolt led by Judas the Galilean under Coponius (II 118). ${ }^{99}$ Furthermore, descriptions of the three Jewish schools (II 119-66), of the reigns of Philip and Antipas, of Pilate's time as governor of Judea (II 169-77), of the Gaius Caligula crisis, of Agrippa I and II, and of the procurators of Judea until the 60s are given. This period is marked by increasing tensions between the Jews and the Romans, but, at the same time, conflicts between Jews and Gentiles are also described. We are told about Jewish rebels, Cestius Gallus' campaign against Jerusalem, and his unexpected defeat (II 499-555). Finally, Josephus tells us about a rebellious Jewish government in Jerusalem and ends with a description of the preparations for the war in Galilee and of corresponding preparations in Jerusalem during the winter of 66-7 C.E. (II 569-654). Although it relates to the uprising of Judas under Coponius, the passage about Pilate belongs to a time of direct Roman rulership showing relative tranquility and satisfaction of the people. His long excursus on the three philosophical schools contributes to this

93 This is the major part that is of interest to us. Among this, there are two brief references to him in XVIII 35 and in XVIII 177.

94 See for example the overview in (Mason 2005, p. 34).

95 See also the statement of (Bond 2000, p. 213): "What Josephus wants to say about Pilate, therefore, can be understood only if the stories about the prefect are seen as part of the larger narrative."

96 For further information, see the work of (Mason 2005, pp. 64-99 [concerning the War]) and (Mason 2005, pp. 99121 [concerning the Antiquities]). Historical evaluations of Josephus' accounts will be done here only with regard to the actions of Pilate.

97 On this topic, see also (Stowasser 2008 [non vidi]).

98 For the following and for a more detailed view on this, see (Bilde 1988, pp. 65-79).

99 It should be noted that there is a contrast to (Josephus 1927, II, par. 433), which connects the rebellion of Judas with the Syrian governor Quirinius. 
relatively harmonious impression of Judea between the reigns of Archelaus and Caligula and Agrippa I. ${ }^{100}$

With regard to the purpose ${ }^{101}$ of the War, we have to keep in mind the outcome of the war for the Jews, which was disastrous. Josephus' first aim in the War is therefore to deal with this catastrophe for the Jewish people and to prevent a repetition of it by trying to convince them that some of them ${ }^{102}$ chose the wrong solution. ${ }^{103}$ By analyzing the causes of the war, he places the blame with the Jews themselves, because those who were in favor of the war did not observe the law.104 Moreover, he wants to reject all militant nationalism and Messianism, because Rome is too powerful. This is demonstrated in many ways in the War, especially in the speeches of Agrippa II. ${ }^{105}$ The point to notice is that Rome received her power from God, and ${ }^{106}$ thus, a revolt against Rome is also a revolt against God. ${ }^{107}$ However, only for a limited time should the Jews accept Roman governorship, waiting patiently until the situation changes. ${ }^{108}$ Therefore, the story of the Jewish uprising against the Romans serves as illustration of what happens when a nation attacks the Romans and is a warning to others of the disastrous consequences. ${ }^{109}$

\subsubsection{The Incident of the Effigies of Caesar}

The relevant passage for our research on Pilate includes the following:

(169) When he [sc. Pilate] had been sent to Judea as procurator by Tiberius, Pilatus introduced into Hierosolyma - by night, concealed - the images of Caesar, which are called 'standards.' (170) After daybreak this stirred up a huge disturbance among the Judeans. For those who were close to the sight were shocked at their laws' having been trampled - for they think it fitting to place no representation in the city - and [in addition] to the indignation of those in the city, the citizenry from the countryside streamed together en masse. (171) They rushed to Pilatus in Caesarea and kept begging him to take the standards out of Hierosolyma and to preserve their ancestral [customs]. But when Pilatus refused, they fell down around his residence, prone, and held out motionless for five days and nights alike. (172) On the next [day] Pilatus sat on a tribunal-platform in the great stadium and, after summoning the rabble as though truly intending to answer them, gave the soldiers a signal, according to a scheme, to encircle the Judeans with weapons. (173) As the infantry column was positioned around threedeep, the Judeans were speechless at the unexpectedness of the sight. After saying that he would cut them to pieces if they would not accept Caesar's images, Pilatus nodded to the soldiers to bare their swords. (174) The Judeans, just as if by an agreed signal, fell down en masse, bent their necks to the side, and shouted that they were ready to do away with themselves rather than transgress the law. Pilatus, who was overwhelmed by the purity of their superstition, directed [his men] immediately to carry the standards out of Hierosolyma. ${ }^{110}$

Pilate is introduced very abruptly to us without any further references to his biography. Because Josephus refers to him by the Greek 'ं $\pi i$ i $\rho \circ \pi \mathrm{s}$ (procurator), ${ }^{111}$ scholars have assumed that the

100 See (Bond 1998, p. 54).

101 Its audience, a Roman one, will not be discussed further here. For a discussion on this, see (Mason 2005, pp. 969). Obviously, Josephus had several motives in writing his account. I mention only the most important one. See Bond (Bond 2000, p. 214).

102 He stresses that the Jewish people as a whole are not responsible for the war. The blame rather falls on small groups of rebels, which are often called tyrants ( $\tau$ ṕavvor, see for example [Josephus 1927, II, par. 10 \{trans. Thackeray, pp. 6-7\}]) or bandits ( $\lambda \eta \sigma \tau \alpha 1$, see for example [Josephus 2008, par. 541 (trans. Mason, p. 372\}]).

103 See for example (Josephus 1927, III, par. 108 [trans. Thackeray, pp. 608-9]).

104 See for example (Josephus 2008, par. 454-6 [trans. Mason, pp. 333-6]).

105 See (Josephus 2008, par. 345-401 [trans. Mason, pp. 269-310]). See also ibid. fn. 2796 on pp. 334-5.

106 See (Josephus 2008, par. 390) (trans. Mason, p. 305).

107 See (Josephus 1928, V, par. 378 [trans. Thackeray, pp. 318-9]).

108 See (Bilde 1988, pp. 76-7).

109 See (Bond 1998, p. 52). There is also a thesis on this task: See (Lindner 1972).

110 (Josephus 2008, par. 169-74 [trans. Mason, pp. 138-45]).

111 His title should be ع̌ $\pi \alpha \rho \chi o \varsigma$ (prefect). See also fn. 720 in Mason's commentary on (Josephus 2008, pp. 79-80). 
emphasis in this account is not on Pilate's governorship itself, but on the two following incidents, especially on the behavior of the Jews. ${ }^{112}$ The reaction of the Jews is based on an initial action of Pilate, which is not regarded further by Josephus. ${ }^{113}$ He does not seem to be interested in why Pilate brought the standards ( $\sigma \eta \mu \alpha \hat{\imath} \alpha)$ into Jerusalem. Although shocked by this, ${ }^{114}$ the Jews remain peaceful and go to Pilate, asking for their removal in order to preserve their laws. ${ }^{115}$ Pilate's refusal gives Josephus a reason to put greater emphasis on the reaction of the Jews than on Pilate's behavior: accepting death rather than a transgression of their laws, they held out ${ }^{116}$ for five days and five nights at his residence. Finally, astonished by their religious devotion, Pilate has his men remove the standards. Therefore, in accordance with Josephus' aims of the War, this account shows that, by respecting the Roman government, a passive demonstration can be successful. ${ }^{117}$

Despite the lack of further information on Pilate's motivation for introducing the standards, it is possible to get a picture of Pilate's character. The fact that they are introduced by night and under cover ( $v v ́ \kappa \tau \omega \rho \kappa \varepsilon \kappa \alpha \lambda \nu \mu \mu \varepsilon \dot{v} \alpha \varsigma$ ) leads to the question of whether his decision was a deliberate act of causing offense or not. ${ }^{118}$ The dominant impression, however, is that of insensitivity toward the Jews under his governorship. By refusing to remove the standards, Pilate shows stubbornness as well as patience, because he let the people remain motionless outside of his residence. ${ }^{119}$ Although remaining completely convinced that the Jews have to accept the images of Caesar, ${ }^{120}$ the situation changes suddenly. Being overwhelmed ${ }^{121}$ by their religious zeal, ${ }^{122}$ he directed ${ }^{123}$ his men to remove the standards in order to respect Jewish Law. Thus, Pilate's behavior here seems to be reasonable rather than being a sign of weakness, ${ }^{124}$ because he did not want to cause a massacre on a passive and unarmed crowed.

\subsubsection{The Incident of the Aqueduct}

The passage concerning the aqueduct follows immediately on the preceding. The text is as follows:

112 See (Bond 2000, p. 215) and (Krieger 1995, pp. 66-8). (Schwartz 1983, p. 32) points it out clearly that often Pilate did not have an accurate picture of the order of events or that he did not intend to narrate them in chronological order. He further observes that "Josephus begins his account of almost every governor with the same terminology ('After NN was sent...' or 'Caesar sent NN...[']), so the reference in War to Pilate's 'having been sent' need not be taken as a chronological indication." For further examples, see also fn. 25 on p. 43.

113 Throughout the whole account, the scheme of action and reaction can be found. See (Bond 2000, p. 215).

114 Greek: $\pi \alpha \tau \dot{\varepsilon} \omega \tau \hat{\omega} v$ vó $\mu \omega v$.

115 The Greek $\tau \dot{\alpha} \pi \alpha ́ \tau \rho 1 \alpha$ is used as a synonym here for laws (oi vó $\mu$ or). See fn. 1070 in Mason's commentary on (Josephus 2008, p. 143).

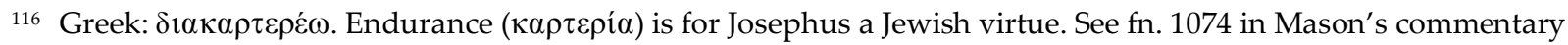
on (Josephus 2008, p. 143).

117 See (Bond 1998, pp. 55-6).

118 Scholars do not agree with respect to this point: (Krieger 1995, p. 67) thinks that this is part of the exposition of Josephus' account and that he therefore does not want to blame him. For (Bond 1998, p. 56), however, this clearly indicates the perpetration of a crime and that Pilate was aware of creating trouble. (McGing 1991, p. 429) and (Lémonon 2007, p. 145) share her opinion. Mason, fn. 1056 in his commentary on (Josephus 2008, p. 140), leaves the question open to answer.

119 See (Bond 1998, p. 58). The five days and five nights of motionlessness are obviously reflecting literary and rhetorical aims.

120 Three times he tried to dispel them: first ignoring them, then intimidating them, and finally threatening them.

121 The Greek $i \pi \varepsilon \rho \theta \alpha u \mu \alpha ́ \zeta \omega$ expresses an extreme wonder and can be found only here in the War. See also fn. 1095 in Mason's commentary on (Josephus 2008, p. 145).

122 Shared by (Lémonon 2007, p. 139): “À chaque étape du récit, les Juifs agissent avec franchise et leur comportement est expliqué par l'absolu de leur zèle religieux [...]."

123 The active verb $\kappa \varepsilon \lambda \varepsilon v \varepsilon \varepsilon 1$ gives the impression that Pilate remains the commander of the situation. See (Bond 1998, p. 59).

124 Against (McGing 1991, p. 429). 
(175) After these [events] he set in motion a different kind of disturbance by exhausting the sacred treasury - it is called the corbonas - on a water conduit; it conducted [water] from 400 stadia away. At this there was indignation among the rabble, and when Pilatus was present at Hierosolyma they stood around his tribunal-platform and kept yelling at [him]. (176) But because he had foreseen their disturbance, he had mixed in amongst the rabble soldiers in arms, but concealed in civilian clothes. Having prohibited them from using the sword, but having directed them instead to beat with sticks those who had begun screaming, he gave the agreed signal from the tribunal-platform. (177) Many Judeans were lost from being hit by blows, but many others from having been trampled under by their very own [people] in the escape. Given the calamity of those who had been taken, the beaten down rabble became silent. ${ }^{125}$

This account bears the same structure as the preceding one. ${ }^{126}$ Although several terms of the first are mentioned also in the second, ${ }^{127}$ it is not simply a variation on it. ${ }^{128}$ It is built around the scheme of cause and effect and also does not give further regard to the motives for Pilate's using of money from the Temple treasury, called $\kappa o \rho \beta \omega v \hat{\alpha} \varsigma_{1}{ }^{129}$ or how he got access to it. ${ }^{130}$ Thus, Pilate's initial offense serves primarily as an occasion to demonstrate Jewish reactions, reactions that also become clear from the first sentence of the account, ${ }^{131}$ which is typical Josephan language. ${ }^{132}$ However, the reaction of the Jews shown in this incident is completely different and, therefore, serves as a counterpart of the preceding story: active and angry protest ${ }^{133}$ against the Romans cannot be successful and will end in a disaster. ${ }^{134}$

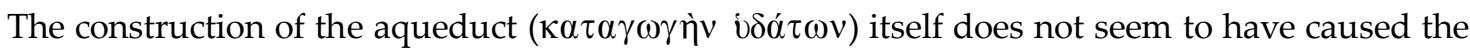
trouble ${ }^{135}$, but, rather, the fact that he exhausted ( $\left.\varepsilon \xi \alpha v \alpha \lambda i \sigma \kappa \omega\right)$ the Temple treasury to do so is problematic. ${ }^{136}$ The indignation $(\dot{\alpha} \gamma \alpha v \alpha \dot{\alpha} \tau \eta \sigma \imath \varsigma)$ caused among the Jews is referred to only in general by the Greek $\pi \rho$ ò $\varsigma$ ôv $\tau 0 .{ }^{137}$ However, now it becomes clear that Pilate was aware of some of the

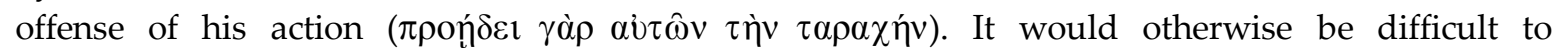
understand why he had mixed soldiers in civilian clothes among the crowd that encircled him at his tribunal platform. Contrary to the incident with the standards, Pilate here seems to avoid an

125 (Josephus 2008, par. 175-7 [trans. Mason, pp. 146-50]).

126 See (Bond 2000, p. 215) and (Krieger 1994, p. 35).

127 For example: indignation, rabble, tribunal-platform, concealed, sword, agreed signal, trampled.

128 See (Krieger 1995, p. 68).

129 Form taken from the manuscripts $\mathrm{P}, \mathrm{L}^{2}$, and corrections of A. The majority of the manuscripts, M, L, V, R, and

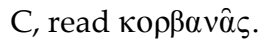

130 See also the statement of (Lémonon 2007, p. 155): “L'impiètement sur la part du trésor réservée aux sacrifices conduit Josèphe à insister sur le caractère sacré du trésor. [...] Pilate n'a donc pas accompli une œuvre illégitime, mais il s'est octroyé un droit qui n'était pas le sien: décider de l'utilisation du trésor [...]." For further considerations on the Temple treasure, see also (Lémonon 2007, pp. 153-5).

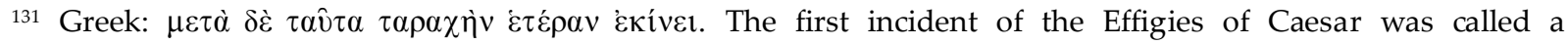

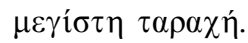

132 See fn. 1098 in Mason's commentary on (Josephus 2008, p. 146).

133 The Greek $\kappa \alpha \tau \alpha \beta$ oó $\omega$ in the War is used exclusively for popular outrage at the behavior of Roman officials. See fn. 1108 in Mason's commentary on (Josephus 2008, p. 148).

134 See (Bond 1998, p. 56). In the following incident on Gaius' statue (II 184-203) the Jews seem to have learned from the incidents with Pilate, appealing peacefully to Petronius. It should also be noticed here that in this scene only

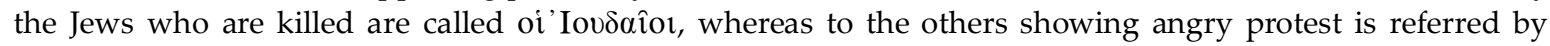
$\tau$ ò $\pi \lambda \hat{\eta} \theta 0 \varsigma$.

135 Notice that Jerusalem was not favorably situated for a water supply and, therefore, Pilate's construction of an aqueduct had also a utilitarian value. For further-also technical-discussions on the aqueduct see fn. 1102 in Mason's commentary on (Josephus 2008, pp. 146-7).

136 It is also possible that the offense was simply caused by confronting the Jews with a fait accompli. See (Lémonon 2007, p. 157).

137 See also the statement of (McGing 1991, p. 429): "It is not clear why [the offense was caused]." Furthermore, it is not at all clear if Pilate acted against a Jewish Law, because there is no reference to the Greek vó $\mu$ o $\varsigma$ (or to its synonyms) as in the preceding incident or in Philo. See also (Krieger 1995, p. 68). 
unnecessary massacre from the very beginning, because instead of directing the use of the sword, he only allows his soldiers to beat those who begin shouting ( $\kappa \propto \zeta \omega)$ ) with sticks after having given the signal. ${ }^{138}$ Because his orders seem to be appropriate to the circumstances, the disastrous outcome of the incident is primarily based on the harsh behavior of his troops and the escape of the Jews. While describing the final silence, this incident shows its tragedy not only because of Pilate's behavior but also because of the protest of the Jews. ${ }^{139}$

\subsubsection{Conclusions-Pilate's Picture in the War}

Despite the lack of further explanations concerning Pilate, both narratives show his insensitivity toward the Jewish religion in the context of conflicts with Roman interests. Beside stubbornness and patience, he can also be impressed by Jewish religiosity and allow this to influence his judgement. As a Roman official he takes seriously the duty of maintaining peace and does not want to cause unnecessary violence. Therefore, he backs down rather than to execute an unarmed crowd, and, furthermore, encounters a disturbance with a minimum of violence. ${ }^{140}$

\subsection{Pilate in the Jewish Antiquities}

Pilate is referred to within four incidents in the Antiquities: the first two, which are also found in the War (standards and aqueduct; XVIII 55-9 and XVIII 60-2), the execution of Jesus (XVIII 63-4; known famously as the Testimonium Flavianum) and the uprising of a Samaritan revolt (XVIII 85-9). Before going into details concerning the four texts themselves, I will briefly consider their contexts within the Antiquities and some general aims of this Josephan work. ${ }^{141}$

Written about twenty years after the War also for a non-Jewish audience, the Antiquities can be divided into two main parts, I-X and XI-XX. Whereas the first is mainly a "paraphrase of the Bible,"142 the second concentrates on the Hasmonaeans (XI-XIII), Herod the Great (XIV-XVII) and his descendants Agrippa I and Agrippa II (XVIII-XX). Being under Roman domination by the governorship of the Herodians, the situation in Israel is characterized by internal strife and conflicts. ${ }^{143}$ Despite his beneficent character the kingdom of Herod the Great mainly reveals his ferocity. ${ }^{144}$ Although transformed into a proper province of the Roman Empire, ${ }^{145}$ confrontations between the Jews and governors, now Roman officials, continue. Therefore, the accounts of Pilate serve as examples for the situation of conflict. ${ }^{146}$ In general, it seems that Josephus is following the parallel version in War II 117-203, which, however, has been expanded in the description of the same events as well as the addition of new material, ${ }^{147}$ e.g., the so-called Testimonium Flavianum (Antiquities XVIII 63-4) and the passages on John the Baptist (Antiquities XVIII 116-19).

With regard to the aim of the Antiquities, the most common view is that it is an apologetic work written for a Greek-speaking audience. Josephus writes against pagan hostility toward Judaism and

138 Because I noticed that this incident can be seen as a counterpart to the preceding, this Josephan information about secret instructions to the troops is probably due to literary composition. See also fn. 1113 in Mason's commentary on (Josephus 2008, p. 149).

139 The Greek $\sigma u \mu \varphi$ $\rho \alpha$ underlines the tragic mood of the incident. See also fn. 1122 in Mason's commentary on (Josephus 2008, p. 150).

140 See (Bond 1998, p. 60).

141 For the following and for a more detailed view on this, see (Bilde 1988, pp. 80-104).

142 (Mason 2005, p. 99).

143 See (Bilde 1988, p. 91).

144 Therefore, see for example the detailed description in (Josephus 1963, XVI, par. 150-9 [trans. Marcus, pp. 26771]).

145 See the passage on the Jewish delegation in Rome blaming the kingdom of Herod the Great and claiming for an end of the Herodian governorship in Judea in (Josephus 1963, XVII, par. 299-314 [trans. Marcus, pp. 510-7]).

146 The Greek refers always to $\theta$ o $\nu$ $\beta \dot{c} \omega$ or $\theta$ ó $\rho$ $\beta$ os. See (Josephus 1965, XVIII, par. 58; 62; $65 ; 85$ [trans. Feldmann, pp. 44-7; 50-1; 60-1]).

147 See (Bilde 1988, p. 88). 
tries to defend his nation against slanders concerning its origins and early history. ${ }^{148}$ This overall aim fits with Josephus' own words in the introduction to the Antiquities:

(5) And now I have undertaken this present work in the belief that the whole Greek-speaking world will find it worthy of attention; for it will embrace our entire ancient history and political constitution, translated from the Hebrew records. ${ }^{149}$

His idea is that the holy scriptures of the Jews are trustworthy not only because of their antiquity but also because of the fact that they are confirmed also by non-Jewish sources. He therefore tries to convince members of the Roman Empire to revert to the former respect toward Judaism by stressing, for example, the value of Jewish Law ${ }^{150}$ and by citing edicts from Roman governors ${ }^{151}$ demonstrating tolerance toward the Jewish religion. Although these themes have also been mentioned in some way in the War-as we have seen in our analysis of the two incidents above-they are of special importance in the Antiquities. ${ }^{152}$

\subsubsection{The Two Parallel Events to the War ${ }^{153}$}

The Antiquities give us more information about Pilate than the War. He is introduced to us the first time as the successor of Gratus as governor of Judea. ${ }^{154}$ Moreover, Josephus also informs us about his departure from the province to Rome because of an order by Vitellius, the Roman governor of Syria. ${ }^{155}$ In general, in the Antiquities, Josephus shows a greater interest in Pilate and his actions than in the War. ${ }^{156}$ The two parallel incidents that are of interest for our work on Pilate are narrated in the following passage:

(55) Now Pilate, the procurator of Judaea, when he brought his army from Caesarea and removed it to winter quarters in Jerusalem, took a bold step in subversion of the Jewish practices, by introducing into the city the busts of the emperor that were attached to the military standards, for our law forbids the making of images. (56) It was for this reason that the previous procurators, when they entered the city, used standards that had no such ornaments. Pilate was the first to bring the images into Jerusalem and set them up, doing it without the knowledge of the people, for he entered at night. (57) But when the people discovered it, they went in a throng to Caesarea and for many days entreated him to take away the images. He refused to yield, since to do so would be an outrage to the emperor; however, since they did not cease entreating him, on the sixth day he secretly armed and placed his troops in position, while he himself came to the speaker's stand. This had been constructed in the stadium, which provided concealment for the army that lay in wait. (58) When the Jews again engaged in supplication, at a prearranged signal he surrounded them with his soldiers and threatened to punish them at once with death if they did not put an end to their tumult and return to their own places. (59) But they, casting themselves prostrate and baring their throats, declared that they had gladly welcomed death rather than make bold to transgress the wise provisions of the laws. Pilate, astonished at the strength of their devotion to the laws, straightway removed the images from Jerusalem and brought them back to Caesarea. (60) He spent money from the sacred treasury in the construction of an aqueduct to bring water into Jerusalem, intercepting the source of the stream at a distance of 200 furlongs. The Jews did not acquiesce in the operations that this involved; and tens of thousands of men assembled and cried out against him, bidding him relinquish his promotion of such

148 See (Bilde 1988, p. 99) and (Mason 2005, p. 100).

149 (Josephus 1930, I, par. 5 [trans. Thackeray, pp. 4-5]). For a more detailed analysis of his prologue, see (Mason 2005, pp. 103-21).

150 See for example (Josephus 1965, XVIII, par. 266-8 [trans. Feldman, pp. 156-9]).

151 See for example (Josephus 1963, XVI, par. 174 [trans. Marcus, pp. 278-9]).

152 See (Bond 1998, p. 63).

153 I will discuss the two incidents primarily with regard to their differences to the versions in the War. For a synoptic overview on both accounts, see (Lémonon 2007, pp. 136-8, and 150-1).

154 See (Josephus 1965, XVIII, par. 35 [trans. Feldmann, pp. 30-1]).

155 See (Josephus 1965, XVIII, par. 89 [trans. Feldmann, pp. 62-3]).

156 And, vice versa, the descriptions of the reactions of the Jews have been minimized. See (Bond 2000, p. 219). 
designs. Some too even hurled insults and abuse of the sort that a throng will commonly engage in. (61) He thereupon ordered a large number of soldiers to be dressed in Jewish garments, under which they carried clubs, and he sent them off this way and that, thus surrounding the Jews, whom he ordered to withdraw. When the Jews were in full torrent of abuse he gave his soldiers the prearranged signal. (62) They, however, inflicted much harder blows than Pilate had ordered, punishing alike both those who were rioting and those who were not. But the Jews showed no faintheartedness; and so, caught unarmed, as they were, by men delivering a prepared attack, many of them actually were slain on the spot, while some withdrew disabled by blows. Thus ended the uprising. ${ }^{157}$

Contrary to in the War, Josephus first gives a superficial reason for introducing the standards ${ }^{158}$ into Jerusalem: the removal of his troops to the winter quarters in Jerusalem. However, Josephus refers

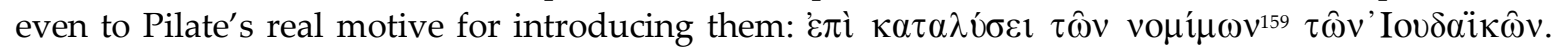
Besides this, by stressing the prohibition of images according to the law ${ }^{160}$ and by contrasting his behavior with that of the preceding governors, ${ }^{161}$ it becomes clear that Pilate deliberately wants to provoke the (uninformed) ${ }^{162}$ Jews. ${ }^{163}$ The Jewish reaction, compared with that in the War, has been shortened here in their entreating ${ }^{164}$ for the removal of the images for many days ${ }^{165}$. Furthermore, Pilate's refusal to do this is explained here, although his motive was lacking in the War:

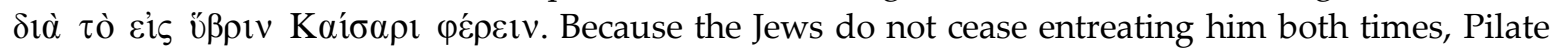
feels himself obligated to react: first by secretly ${ }^{166}$ hiding his armed troops in the stadium ${ }^{167}$ and secondly by directing them to surround the Jews in order to threaten to put them to death ${ }^{168}$ if they do not stop their disturbance. Thus, the Antiquities focus the situation of the Jews in front of Pilate more on the aspect of entreating the governor than on a motionless resistance as in the War. ${ }^{169}$ Finally, the outcome of the incident is very similar to that in the War: the Jews, gladly accepting death rather than the transgression of the wise provisions of their laws, ${ }^{170}$ bare their necks, and Pilate at that moment $^{171}$ removes $^{172}$ the images, because he is impressed ${ }^{173}$ by the strength of their devotion ${ }^{174}$.

This incident, therefore, shows Josephus' interest in Pilate's personal history as a Roman governor, particularly his attitude toward Jewish Law. His determination to honor Caesar shows his ruthlessness toward Jewish sensitivities and leads into a conflict with the Jews for not accepting a transgression of their laws, for which it is worth suffering. Finally, the strength of their devotion to

157 (Josephus 1965, XVIII, par. 55-62 [trans. Feldmann, pp. 42-7]).

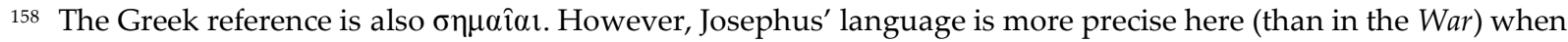

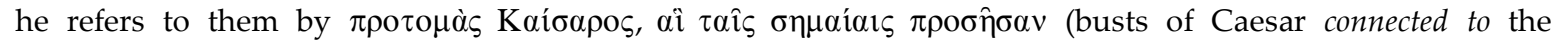
standards).

159 The manuscripts M, W, and E show the form vó $\mu \omega v$, which is also evidenced by the parallel in the War.

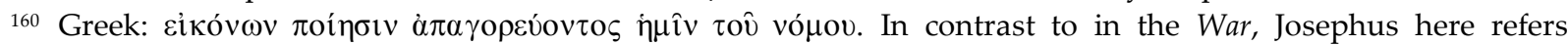
explicitly to himself as a member of the Jews.

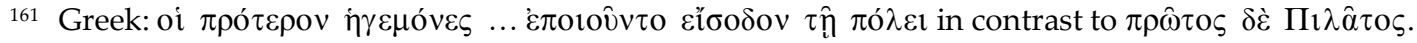

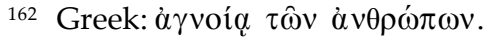

163 See (Krieger 1995, p. 70) and fn. 1058 in Mason's commentary on (Josephus 2008, p. 140). The motive of the introduction by night can also be found here.

164 Greek: $\lambda 1 \pi \alpha \rho \varepsilon \dot{\omega}$.

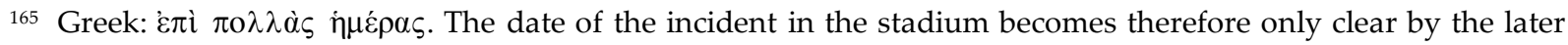
notice $\kappa \alpha \tau \grave{\alpha} \check{\varepsilon} \kappa \tau \eta \nu \dot{\eta} \mu \varepsilon \dot{\varepsilon} \rho \nu$.

166 Greek: àqavôs. This detail is not given in the War.

167 For this see fn. 1077 in Mason's commentary on (Josephus 2008, p. 143).

168 The swords are not mentioned.

169 See (Lémonon 2007, p. 140).

170 Contrary to in the War, Jewish Law here is characterized further by its wisdom (бopí $\alpha$ ) and the reaction of the Jews by their pleasure (i்oví).

171 Greek: $\pi \alpha \rho \alpha \chi \rho \hat{\eta} \mu \alpha$.

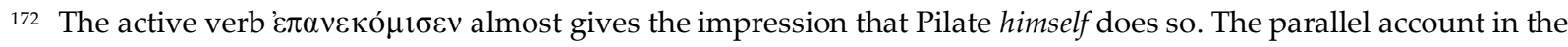
War refers to an order.

173 Greek: $\theta \alpha v \mu \alpha ́ \sigma \alpha \varsigma$.

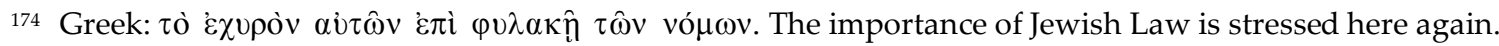


their laws is the point, which results in Pilate removing the standards. ${ }^{175}$ Thus, compared with the War, the version in the Antiquities reflects a completely different style, i.e., the importance of devotion to Jewish Law, while narrating the same event. ${ }^{176}$

Concerning the construction of the aqueduct, ${ }^{177}$ however, Pilate's motives remain as unclear as in the War, but the construction of the account seems to be more neutral at the beginning: Pilate's action is not qualified as causing another kind of disturbance as did that in the War, and, furthermore, Josephus does not mention the exhaustion of the sacred treasury. ${ }^{178}$ Moreover, the reaction of the Jews seems to be toned down to some extent in the present version: they do not acquiesce in the

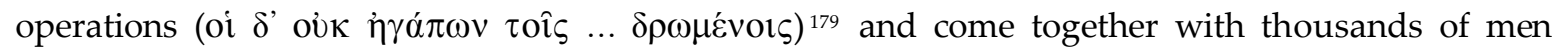

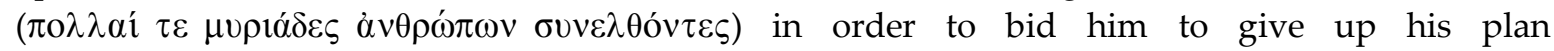

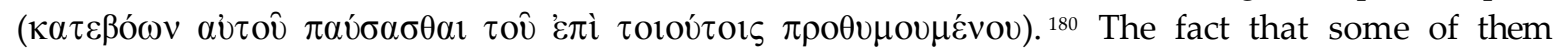

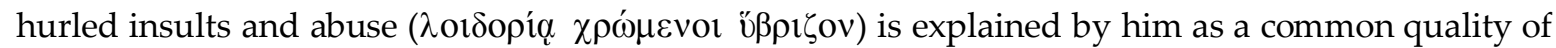

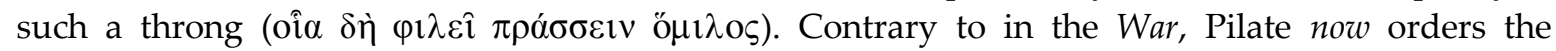
soldiers, ${ }^{181}$ dressed in Jewish clothes and carrying clubs under them, ${ }^{182}$ to surround the Jews. Because the Jews refuse to withdraw and continue insulting Pilate, he gives the pre-arranged signal to the soldiers. The differences Josephus is insisting on in his version of the Antiquities become clear in the following scene: the behavior of the soldiers ${ }^{183}$ (by arrangement) ${ }^{184}$ and of the Jews. Ignoring apparently a directive of Pilate, which is not mentioned explicitly, they strike the Jews much harder

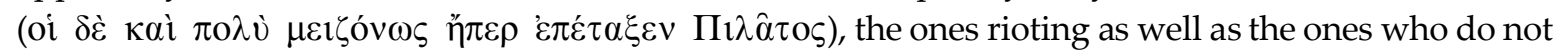

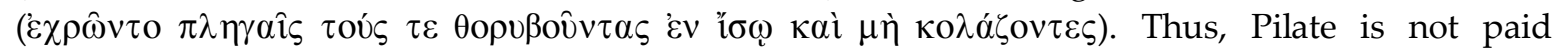
much attention to, because responsibility for this ferocious act lies on the soldiers. Furthermore, the incident lacks the dramatic ending it has in the War: all the dead and injured are victims of the attack of the troops, and nobody is trampled under by compatriots in the escape. ${ }^{185}$ Josephus, however,

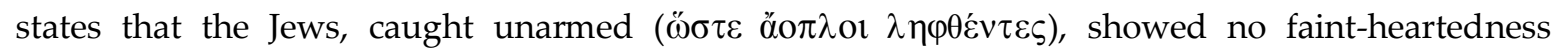

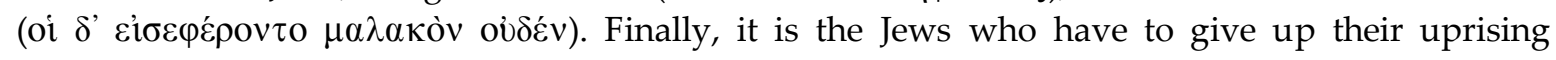

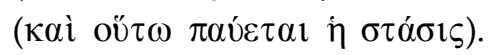

Therefore, this incident has its central focus not so much on Pilate's offense or on the protest of the Jews but, rather, on their attitude in the case of a violent attack from pagan soldiers. ${ }^{186}$ While in the first incident, the Jews were able to impress Pilate by their religious zeal, now they are really dying for it. ${ }^{187}$

175 See (Bond 2000, p. 220).

176 Shared by (Lémonon 2007, p. 140): “Josèphe, tout au long du récit des Antiquités, insiste moins que dans la Guerre des Juifs sur l'attachement aux lois."

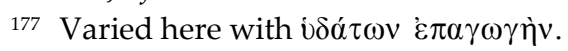

178 See (Lémonon 2007, p. 152). It is said that he spent (" $\check{\pi} \rho \alpha \xi \varepsilon v)$ money for the aqueduct.

179 Josephus' reference to the Jews here as oi $\delta$ ' shows that this account is also connected with the preceding one. In the War, however, Josephus referred to those protesting against Pilate as $\tau \grave{o} \pi \lambda \hat{\eta} \theta 0 \varsigma$.

180 Josephus here puts emphasis on the number of Jews coming together. He already supposes the presence of Pilate in Jerusalem.

181 More exactly: a large number of soldiers $(\pi \circ \lambda \grave{v} \pi \lambda \hat{\eta} \theta 0 \varsigma \sigma \tau \rho \alpha \tau \iota \omega \tau \hat{\omega} v)$.

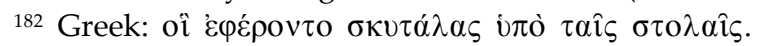

183 This is described in much more detail than in the War.

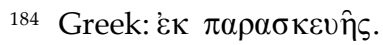

185 See (Bond 1998, p. 70).

186 See (Bond 1998, p. 70).

187 That there is a connection between these two narrates on the literary level has already been mentioned above. See also the statement of (Krieger 1994, p. 40): “18, 60-62 ist auch in einem ,positiven' Sinn Steigerung gegenüber 18, 55-59. Die in 18, 59 bekundete Todesbereitschaft wird in 18, 62 eingelöst." 


\subsubsection{The So-Called Testimonium Flavianum ${ }^{188}$}

The passage on Jesus in the Antiquities is as follows:

(63) About this time there lived Jesus, a wise man, if indeed one ought to call him a man. For he was one who wrought surprising feats and was a teacher of such people as accept the truth gladly. He won over many Jews and many of the Greeks. He was the Messiah. (64) When Pilate, upon hearing him accused by men of the highest standing amongst us, had condemned him to be crucified, those who had in the first place come to love him did not give up their affection for him. On the third day he appeared to them restored to life, for the prophets of God had prophesied these and countless other marvellous things about him. And the tribe of the Christians, so called after him, has still to this day not disappeared. ${ }^{189}$

Pilate is referred to only very briefly here, whereas the center of attention is Jesus and his followers. Although the present author shares the opinion that the Testimonium Flavianum was originally written in some way by Josephus, regarding the context probably by remembering another disturbance, the majority of scholarship thinks that the present version was altered by a Christian interpolator. The original wording is now lost, and therefore, the Josephan motive for introducing the text here is not recognizable anymore. The present text adds very little regarding the portrait of Pilate in the Antiquities. ${ }^{190}$ Pilate seems to be competently putting down a tumult by executing the leader.

\subsubsection{The Samaritan Uprising}

The fourth and last incident taking place during Pilate's governorship is narrated in the following passage of the Antiquities:

(85) The Samaritan nation too was not exempt from disturbance. For a man who made light of mendacity and in all his designs catered to the mob, rallied them, bidding them go in a body with him to Mount Gerizim, which in their belief is the most sacred of mountains. He assured them that on their arrival he would show them the sacred vessels which were buried there, where Moses had deposited them. (86) His hearers, viewing this tale as plausible, appeared in arms. They posted themselves in a certain village named Tirathana, and, as they planned to climb the mountain in a great multitude, they welcomed to their ranks the new arrivals who kept coming. (87) But before they could ascend, Pilate blocked their projected route up the mountain with a detachment of cavalry and heavyarmed infantry, who in an encounter with the firstcomers in the village slew some in a pitched battle and put the others to flight. Many prisoners were taken, of whom Pilate put to death the principal leaders and those who were most influential among the fugitives. (88) When the uprising had been quelled, the council of the Samaritans went to Vitellius, a man of consular rank who was governor of Syria, and charged Pilate with the slaughter of the victims. For, they said, it was not as rebels against the Romans but as refugees from the persecution of Pilate that they had met in Tirathana. (89) Vitellius thereupon dispatched Marcellus, one of his friends, to take charge of the administration of Judaea, and ordered Pilate to return to Rome to give the emperor his account of the matters with which he was charged by the Samaritans. And so Pilate, after having spent ten years in Judaea, hurried to Rome in obedience to the orders of Vitellius, since he could not refuse. But before he reached Rome Tiberius had already passed away. ${ }^{191}$

This incident is not based on an action by Pilate but describes his reaction toward a Samaritan disturbance. As in the Testimonium Flavianum, the focus is not on Pilate himself but, rather, on the activities of the Samaritans and their leader who is described as a man of false qualities:

188 For more detailed studies on this, see (Whealey 2007) and (Horn 2007). For a very different view on Whealey, see for example (Olson 1999). His opinion is that there is no convincing evidence that Josephus wrote any part of it. For a recent study on this, see also: (Niemand 2008).

189 (Josephus 1965, XVIII, par. 63-4 [trans. Feldmann, pp. 48-51]).

190 See (Bond 1998, p. 71).

191 (Josephus 1965, XVIII, par. 85-9 [trans. Feldmann, pp. 60-5]). 


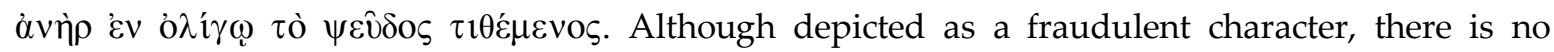

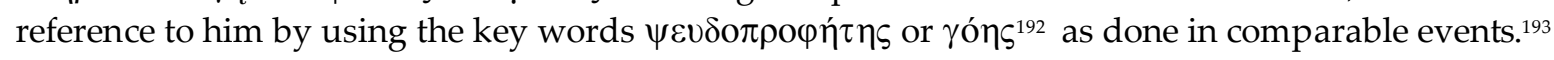
However, the story given here fits with the bad image, which emerges from other narratives in the Antiquities. ${ }^{194}$ Assuming that he will find the sacred vessels ( $\tau \dot{\alpha}$ i $\left.\varepsilon \rho \alpha े ~ \sigma \kappa \varepsilon v ́ \eta\right){ }^{195}$, which have been deposited on Mount Gerizim by Moses, the Samaritan crowd, viewing his story as plausible, gathers together in arms ( $\varepsilon v$ ö $\pi \lambda \mathrm{ol} \varsigma)^{196}$ in a village called Tirathana in order to climb the mountain in a great multitude after having welcomed others. Pilate, however, blocks the route to the mountain with

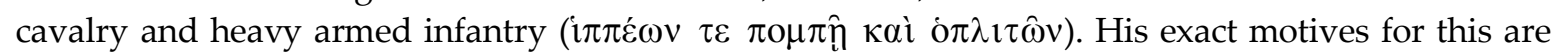
not mentioned. Finally, Pilate puts down the tumult and takes many prisoners, of whom the principal leaders and the most influential ones are executed by Pilate, who, therefore, clearly carries responsibility for this action. Thus, after the uprising, he is charged for this slaughter (ì $\pi \grave{\imath} \tau \hat{\eta} \sigma \varphi \alpha \gamma \eta$ )

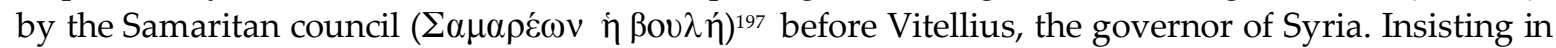
front of him that their meeting was not in rebellion against the Romans but to flee from the

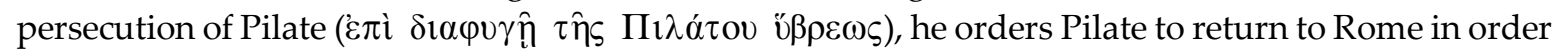
to give Tiberius an explanation of the matters with which he is charged by the Samaritans ${ }^{198}$. Although hurrying (ฤ $\pi \varepsilon i \gamma \varepsilon \tau 0)$, he reaches Rome only after the death of Tiberius ${ }^{199}$.

Similar to the Testimonium Flavianum, Pilate is again confronted with an uprising in his province. Although the motives for the Samaritan gathering are shown not to be rebellious ones later in the account, such a religious movement would certainly lead to repercussions on the political level. With regard also to the preceding account about Jesus, it becomes clear that Pilate could not allow an escalation of such a potentially dangerous movement. ${ }^{200}$ Otherwise, "a Roman governor who did not deal with the situation firmly would be failing seriously in his duty." ${ }^{201}$ Blocking the way to Mount Gerizim with his heavily armed troops, his main aim was to stop their action. Nevertheless, there remains an objection to this motive of Pilate: Josephus mentions that the Samaritans met as refugees from the persecutions of Pilate, which indicates that there were tumults with the governor before. Certainly, Pilate was acting within his rights as a Roman governor when executing their leaders and

192 This is also noted by (Krieger 1994, p. 44).

193 See for example the story on the $\gamma$ óns Theudas (Josephus 1965, XX, par. 97-9 [trans. Feldmann, pp. 440-3]) or

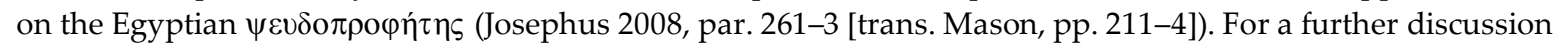

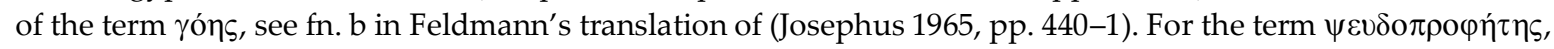
see fn. 1641 in Mason's commentary on (Josephus 2008, p. 212).

194 See for example the description of the events of the founding of the Samaritan Temple on Mount Gerizim in XI, par. 297-347, especially ibid. par. 340-6. See also (Bond 1998, p. 71). The image of the Samaritans in the Antiquities cannot be discussed here further.

195 For more information on this legend, see the summarizing passage in (Lémonon 2007, pp. 217-8). In any case, there is a similarity with a Messianic movement that is not without a political dimension. See (Lémonon 2007, p. 218): “De même que les littératures apocryphe et rabbinique conféraient à la découverte des vases cachés une portée messianique, la tradition samaritaine y reconnaissait la manifestation du prophète eschatologique semblable à Moïse. [...] Une telle perspective ne pouvait que provoquer de l'agitation parmi le peuple et en particulier des oppositions à l'égard des païens. Ce type de mouvement n'était pas sans répercussion au niveau politique."

196 In a more neutral way, $\tau$ ò ö $\pi \lambda \mathrm{ov}$ can also be translated as tool or implement. However, from the further explanations in XVIII 88 (and from the Josephan usage of this word), it becomes clear that the given translation seems to be more likely.

197 For this reason, (Bond 1998, p. 72) presumes that the gathering in Tirathana also had a political motivation.

198 There is an interesting variation on the textual level: Only the codex Ambrosianus (A) reads here oi $\Sigma \alpha \mu \alpha \rho \varepsilon i \tau \alpha 1$.

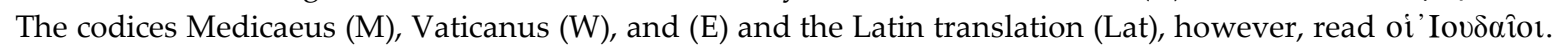
Taking into consideration the latter, therefore, Josephus would also refer back to the incidents with the Jews while speaking about Pilate's dismissal.

199 Tiberius died in 37 C.E. on the $16^{\text {th }}$ of March.

200 See (Bond 1998, p. 91).

201 (McGing 1991, p. 433). 
other influential persons, ${ }^{202}$ but, given the Josephan note, there remains the reproach that the gathering gave him a suitable excuse for getting rid of some uprising Samaritans. ${ }^{203}$

Finally, with regard to the context of the account within the Antiquities, the Samaritan episode serves as the last example of the disturbances ( $\theta$ ópvßot) under the governorship of Pilate. Leaving out further considerations on the point that the present account possibly includes another type of tale, called the "Goeten-Erzählung," ${ }^{204}$ Pilate's dismissal fits with the picture of judgement for those who disrespect Jewish Law. ${ }^{205} \mathrm{He}$ is directed to Rome in order to account for his crimes by Vitellius, who is depicted positively in the Antiquities and, thus, can be regarded as a counterpart to the figure of Pilate. ${ }^{206}$ Therefore, the mentioned textual variant in Antiquities XVIII 89, although it does not respect the context, could give the correct sense intended by Josephus, "that an unpleasant fate awaits those who attempt to tamper with the Jewish law." 207

\subsubsection{Conclusions-Pilate's Picture in the Antiquities}

The Antiquities, more than the War, stress the behavior of Pilate toward Jewish Law. Therefore, in the first incident, his action in honor of Caesar is qualified as a clear transgression of them, whereas it remains unclear in the second. Moreover, both incidents emphasize the religious devotion of the Jews whose acceptance of death in the aqueduct affair marks their absolute loyalty to Jewish Law. This is contrasted with the ferocious attack of pagan troops. Furthermore, he competently puts down the two (religious) uprisings, showing that he is a dutiful Roman governor. However, from the Samaritan tumult, a question emerges regarding the extent to which his actions are opportunistic. Despite his generally competent action toward uprisings, his final dismissal, according to Josephus' rhetorical aim, is due to his upsetting of Jewish Law. ${ }^{208}$

\section{Pilate in the Gospel of John}

John's description of the Roman trial is much longer than those given by the synoptics. ${ }^{209}$ Certainly, as with these, theological issues have influenced his depiction of Jesus and of Pilate. ${ }^{210}$ Concerning the former, the trial reveals clearly the contrast between his exaltation and his humiliation. Furthermore, throughout the trial, John stresses the meaning of Jesus' kingship, which, obviously, differs from the meaning of kingship for Pilate (and for the Jews). Thus, one gets the impression that the main characters, Jesus and Pilate (and also the Jews), do not really understand each other. ${ }^{211}$ Given this, we are already confronted with the important Johannine dualism of 'being of the world' and 'not being of the world,' i.e., those who believe in Christ and those who do not. This is reflected in the concept of $\dot{\alpha} \lambda \dot{\eta} \theta \varepsilon 1 \alpha$ : because God is the truth, Jesus is that truth, because he is one

202 See (Bond 1998, p. 91), and also the statement of (Lémonon 2007, p. 219): “En agissant ainsi, Pilate ne faisait rien d'autre que d'user d'un droit qui lui était reconnu."

203 Against (Bond 1998, p. 91) and (Lémonon 2007, p. 219).

204 (Krieger 1994, p. 44).

205 See (Bond 1998, p. 73).

206 See for example (Josephus 1965, XVIII, par. 90-5; 120-2 [trans. Feldmann, pp. 64-9; 84-5]).

207 (Bond 2000, p. 221).

208 (Bond 1998, p. 78).

209 See (Bond 1998, p. 168). Apart from the works that are treated here, there are two other important ones: (Kertelge 1988) and (Strobel 1980).

210 See the statement of (Blank 1959, p. 60): “Man darf wohl behaupten, dass die Passionsgeschichte bei Joh[annes] im Vergleich mit den Syn[optikern] am bewusstesten und konsequentesten in den Dienst theologischer Leitgedanken gestellt wurde."

211 Shared by (Blank 1959, p. 60): “Es überschneiden sich hierbei: 1. das $\beta \alpha \sigma \imath \lambda \varepsilon v ́ \varsigma$-Verständnis der Juden; 2. das des Pilatus (im Anhang an dieses); 3. das Jesu selbst." 


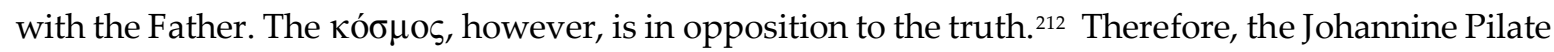
must make a choice either for or against Jesus. ${ }^{213}$

John 18 and 19 are the relevant chapters for our work on Pilate. However, the following analysis will only pay attention to the Roman trial within those chapters, as well as leaving aside further considerations on the background of John's gospel.

\subsection{The Characterization of Pilate in John 18 and 19}

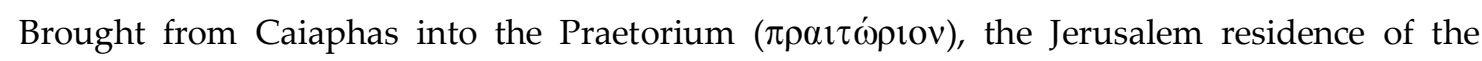
governor during the feasts, Jesus' trial in front of Pilate begins. Based on the movements of Pilate between the Jews and Jesus, ${ }^{214}$ I will divide the passage into seven scenes:215

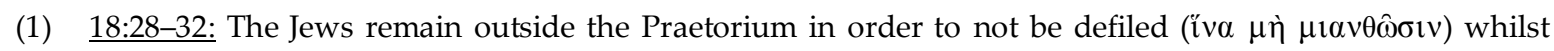
Jesus has been led inside. Respecting Jewish sensibilities, Pilate, who is introduced abruptly, comes out of the Praetorium in order to speak with them. Because he obviously does not know the exact charge, Pilate

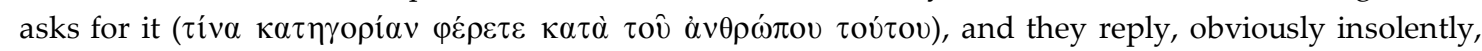
that they would not have handed Jesus over to him, if he were not a criminal. ${ }^{216}$ Pilate, however, wants

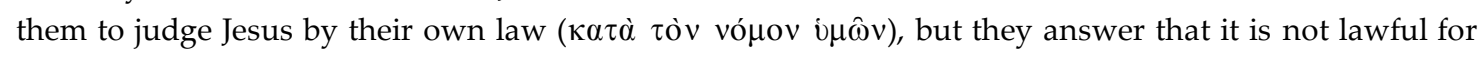
them to put someone to death. The question is how to interpret Pilate here? As prefect of Judea, he must have known that executions are not lawful to the Jews. ${ }^{217}$ Therefore, Pilate is mocking Jewish impotence and asserts his position as Roman governor as the only person who is able to judge Jesus. ${ }^{218}$

(2) 18:33-8a: Going inside the Praetorium, Pilate asks Jesus if he is the King of the Jews. ${ }^{219}$ His rhetorical

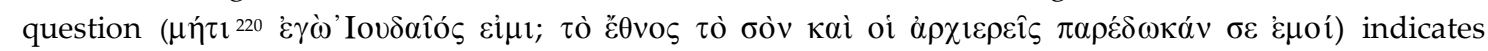
that the charge is Jewish and distances Pilate at the same time from them. ${ }^{221}$ Pilate obviously has no prior knowledge of Jesus' activity and so he asks: “What have you done?” By giving a description of his kingdom, which obviously is not a political one, ${ }^{222}$ Jesus completely ignores this question. For Pilate, the important

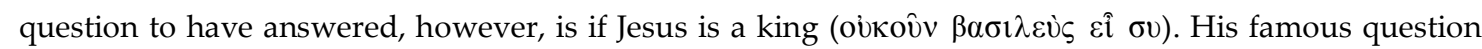

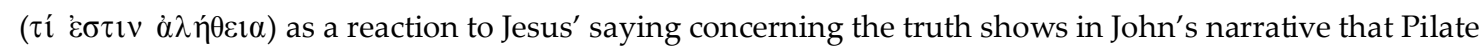

212 See the prologue, John 1:1-18.

213 See (Bond 1998, p. 174).

214 Which takes place as a function of John's literal style, rather than in order to make Pilate appear indecisive.

215 The difficulty is, as we shall see further on, how to interpret Pilate's reaction as well as that of the Jews. There are certainly various possibilities for interpretation. Here, I am going to follow mainly the view of Bond, which I find more convincing. It will not be possible to pay attention to every detail of this passage in John.

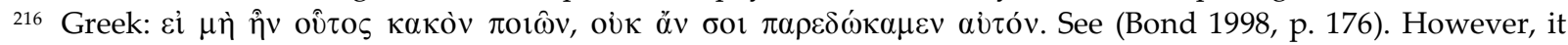
could also show the inability of the Jews to present a water-tight charge. See also (Blank 1959, p. 67).

217 It should be noted that within the Gospels, this is mentioned only by John. However, there is a whole discussion on this issue in the scholarship. See for example (Egger 1997, pp. 44-50), who confirms this detail mentioned in John. This view is shared by (Blinzler 1969, p. 278): “Hat Pilatus geahnt, dass es auf den Tod Jesu abgesehen war, dann haben natürlich seine Worte einen spöttischen Unterton; er musste ja ebenso wie die Juden wissen, dass diese das Tötungsrecht verloren hatten."

218 See (Bond 1998, p. 177).

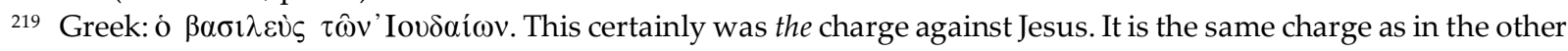
gospels. See the statement of (Egger 1997, p. 200): “Es ist das gesamte öffentliche Tun Jesu, das sich vor dem Richterstuhl des Pilatus in mannigfaltigen Anklagen widerspiegelt und in dem facettenreichen , $\beta \alpha \sigma 1 \lambda \varepsilon v \varsigma^{\prime}$ Titulus beredten Nachhall findet." Further considerations on Jesus' kingdom will not be handled here. For more on this, see for example (Blank 1959, pp. 61-2).

220 This expects a negative answer. Compare this with (Tuckett 2000, p. 135), who thinks that it would leave open the possibility of a positive answer.

221 However, according to John's theology, the statement of (Tuckett 2000, p. 135) can be seen as correct: “Yet as the story goes on, it will become clear that Pilate's position, by being opposed to Jesus, is exactly that of 'the Jews.' He is by the end a 'Jew' in that he fails to acknowledge Jesus."

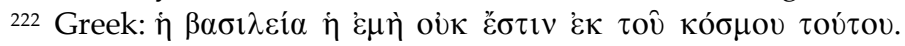


is part of the unbelieving world, which, like the Jews, rejects Jesus. It is impossible for him to recognize the truth and to hear Jesus with understanding and believe. ${ }^{223}$

(3) 18:38b-40: Pilate goes outside, declaring that he finds no guilt in Jesus. However, instead of offering to release Jesus, he himself ${ }^{224}$ refers to a custom ${ }^{225}$ by which he should release one prisoner at Passover. The Jews reply that they want Barabbas to be released, who is only characterized further by being a $\lambda \eta \sigma \tau \eta \varsigma$,

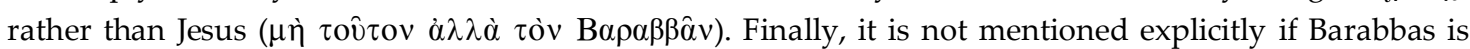
really going to be released. The main question that emerges from this scene and that, in the final analysis, cannot be answered, ${ }^{226}$ is the following: Does Pilate really intend to release Jesus? If so, why does he not simply set him free?227 Moreover, why does he refer to Jesus as the 'King of the Jews,' 228 which seems to mock them and their nationalistic hopes, because they want Jesus to be put to death. Generally, this passage is interpreted as showing Pilate's weakness as a Roman governor toward the Jewish high priests and the Jewish crowd. ${ }^{229}$ However, it is more plausible that Pilate does not intend seriously to release Jesus. ${ }^{230}$ The prefect knows that they want Jesus to be executed, but takes the opportunity to mock their messianic aspirations and, indirectly, the prisoner himself. ${ }^{231}$

(4) 19:1-3: Pilate scourges Jesus. The verb form ' $\varepsilon \mu \alpha \sigma \tau$ í $\gamma \omega \sigma \varepsilon v$ implies that Pilate himself did so, but, probably, this shows his responsibility for this action. His motives for the scourging are unclear. Moreover, this was usually done before crucifixion, which is not even mentioned until the following scene. ${ }^{232}$ The soldiers are

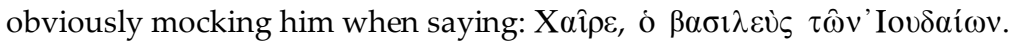

(5) 19:4-8: Pilate goes outside once again, this time bringing Jesus to them in mock kingly clothes (crown of thorns and the purple robe) because he cannot find (political) guilt in him. ${ }^{233}$ The chief priests cry for crucifixion, and Pilate replies that the Jews themselves should crucify Jesus, because he finds no guilt in him. However, now they bring a religious charge: because Jesus made himself the 'Son of God'

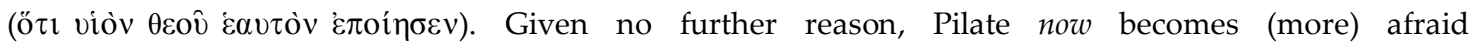
( $\mu \hat{\alpha} \lambda \lambda$ ov $\varepsilon \varphi \circ \beta \eta \dot{\theta} \theta)$. Apparently, Pilate is continuing his mockery of the Jews when he, for the second time, wants them to judge Jesus themselves, ${ }^{234}$ because as to him, Jesus does not seem to be a person causing serious disturbance. They, however, change their tactic by bringing a religious charge, which has an effect on the governor's behavior at this ${ }^{235}$ moment toward Jesus, who now appears to him as a higher being. ${ }^{236}$

(6) 19:9-11: Consequently, Pilate enters the Praetorium again asking Jesus for his origin ( $\pi$ ó $\theta \varepsilon v$ عî $\sigma v)$. Pilate mentions that he has the power $(\xi \xi \text { ov } \sigma i \alpha)^{237}$ to release Jesus or to crucify him. Jesus, however, refers to the

223 See (Bond 1998, p. 179).

224 This, for example, distinguishes John from the account of the synoptics.

225 Its origins are explained differently. For an overview on the sources of Jewish and Roman laws dealing with this, see (Blinzler 1969, pp. 301-20).

226 See already the phrase of (Bajsić 1967, p. 8): “Die Psyche des Prokurators bleibt weiterhin ein Rätsel."

227 Question also put by (Blank 1959, p. 72): “Doch warum läßt Pilatus Jesus nicht frei?"

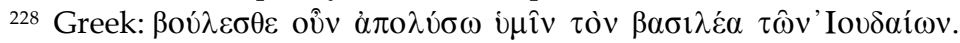

229 See for example the rather convincing view of (Bajsić 1967, p. 12): “Pilatus kann also gegen den Willen des Volkes nichts ausrichten, nicht aus bloßer Angst vor dem Tumult [...], sondern weil ihm dazu die juridische Handhabe fehlt." Pilate's weakness is therefore due to Jewish traditions concerning the question of an amnesty. See also (Bajsić 1967, pp. 13-4).

230 Against (Bajsić 1967, p. 9): “Es wird bestimmt niemand bezweifeln, dass Pilatus sich sehr für die Freilassung Jesu einsetzte." At any rate, until this point in John's account, his statement has to be regarded as not applicable. It may be correct to some extent with regard to the seventh scene. However, Pilate's motives for releasing Jesus remain unclear.

231 See (Bond 1998, pp. 181-2).

232 See (Bond 1998, p. 183). Therefore, the statement of (Blank 1959, p. 73) is correct: “Juristisch handelt es sich freilich um eine Kompetenzüberschreitung und eine Willkürmaßnahme [...]."

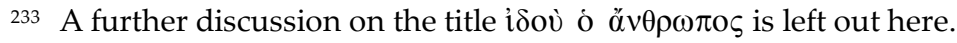

234 See (Tuckett 2000, p. 137): “Yet for John's Pilate this too is just a mocking jest. John's Pilate knows that the Jews are not allowed to execute anyone, as the Jews have already told him this explicitly in the story earlier in 18,31."

235 Consequently, as we have seen, there were no indications for a fear of Pilate in the preceding scenes.

236 See (Bond 1998, p. 187).

237 The central question here is the following: what is the exact meaning of it? Most scholars agree that it refers to the legal power of a Roman governor in his own province. See for example (Blank 1959, p. 78). 
derivation of this power from God. ${ }^{238}$ Moreover, he says, the one who handed him over (í $\left.\pi \alpha \rho \alpha \delta o u ́ \varsigma\right)$ has the greater $\sin$. It remains unclear to whom Jesus is referring here exactly, to the Jews who have handed him over to Pilate or to Judas. ${ }^{239}$

(7) 19:12-6a: At this, Pilate tries to release ( $\alpha \pi \mathrm{o} \lambda \hat{v} \sigma \alpha 1)$ Jesus. ${ }^{240}$ However, what exactly has brought him to this change of attitude is not mentioned. The Jews, obviously realizing that their religious charge has produced the wrong reaction of the governor, revert to the political one: if Pilate releases Jesus, he will not be a friend

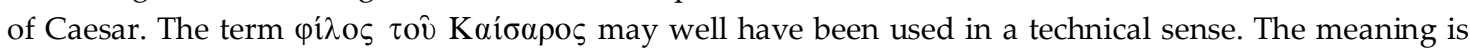
clear: if Pilate releases Jesus as a messianic pretender, he will not be protecting the interests of the emperor. This argument has the desired effect on him: he brings Jesus outside. ${ }^{241}$ Finally, by claiming that the emperor is their only king, Pilate hands Jesus over ( $\pi \alpha \rho \varepsilon \delta \delta \kappa \varepsilon v)$ to the Jews.

\subsection{Conclusions - Pilate's Picture in John}

Keeping in mind the basic difficulty concerning the interpretation of Pilate's actions, the analysis has shown that Pilate does not appear as a weak and indecisive governor. His general behavior fits with his own statement that he has the power ( $\xi \xi o v \sigma i ́ \alpha)$ to release Jesus or to crucify him. Therefore, as a dutiful Roman governor, he takes the case seriously but soon realizes that Jesus is an innocent man with regard to political charges. Nevertheless, he does not release him. The motives for this remain unclear.

The ongoing trial, however, reveals Pilate's mockery of Jewish messianic aspirations with respect to the prisoner himself and would be hard to understand if Pilate was a weak governor. He only stops mocking after the Jews have brought a religious charge to him and tries to release Jesus because he has become afraid, as a pagan governor, of Jesus who appears to him as some kind of a divine man. Finally, the situation changes because of a further political charge offered by the Jews, which raises the danger for Pilate, as a Roman governor, to be blamed for not having protected the interests of the emperor because, apparently, Jesus seems to claim some kind of kingship that could oppose the emperor. Thus, he releases Jesus to the Jews but only after they have accepted the sovereignty of Caesar. According to the Johannine theology, Pilate and the Jews act in the passage dealt with as members of the world, which does not accept Jesus. ${ }^{242}$

\section{Conclusions-The Pilate of Philo, Josephus, and John}

As one of the seven governors of Judea between 6 and 41 C.E., Pontius Pilate was charged with maintaining law and order in the province. The province presented many difficulties: ${ }^{243}$ one reason for this can be seen in the fact that it was composed of different ethnic groups. ${ }^{244}$

The present study on him is limited insofar as it deals with a selection of the sources that refer to Pilate. The event of the Gilded Shields recorded by Philo illustrates Pilate's attempt to show loyalty to his emperor during troubled times rather than to cause unintentional offenses. Pilate's extreme negative depiction is due to Philo's harsh vocabulary, which appears to have been used for corrupt governors more generally. However, after having been already in office for some years, Pilate can be blamed for his insensitivity toward Jewish traditions.

With regard to Josephus, the episodes concerning the standards and the aqueduct are each narrated twice by him. The former show Pilate as a stubborn and insensitive ruler, as well as putting

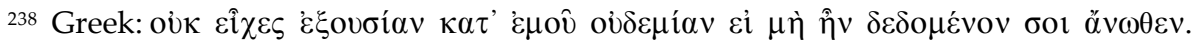

239 Judas is also referred to in John 18:2 by the verb $\pi \alpha \rho \alpha \delta i ́ \delta \omega \mu$. See (Bond 1998, pp. 188-9).

240 This is the first time that the governor attempts to free him.

241 The whole question of whether Pilate (or Jesus?) has taken place on the $\beta \hat{\eta} \mu \alpha$ is left out here. For more on this, see (Blinzler 1969, pp. 346-56). Again, Pilate is mocking the Jews when he is referring to Jesus as their king

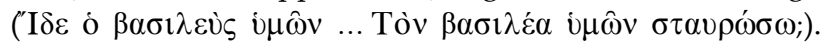

242 See (Bond 1998, pp. 192-3).

243 Shared by (Krieger 1995, p. 82): “Zu berücksichtigen ist ferner, dass Rom mit einem Präfekten aus dem Ritterstand bewusst einen Militär an die Spitze Judäas stellte. Indem dieses Gebiet unter die Provinzen der dritten Kategorie eingeordnet wird, gilt es per se als Unruheherd, der ständiges hartes Durchgreifen erfordert."

244 For another incident, which has not been treated with here, see (Blinzler 1958, pp. 24-49). 
emphasis on his flexibility when he is impressed by Jewish devotion. Thus, as a Roman governor, he takes seriously the responsibility of maintaining peace. This is little modified in the latter when Pilate encounters the tumult with a minimum of violence. Concerning the two uprisings, the execution of Jesus seems to be a routine crucifixion of a messianic disturber whose followers, however, do not lose their lives. The Samaritan disturbance put down by him confirms this picture of a dutiful Roman governor, preventing escalations in his province. Nevertheless, a question emerges regarding the extent to which Pilate's actions are opportunistic.

Finally, John presents a governor who is sure of his own authority. Moreover, his mockery of the Jews and of Jesus shows some kind of cynicism. He is only willing to go along with Jewish wishes to execute an innocent man in order to protect the interests of Caesar.

From the accounts of Philo, Josephus, and John, therefore, the portrait of Pilate emerges as a loyal and dutiful Roman governor whose main aim is to protect the interests of the emperor in his own province, by ensuring, for example, peace and loyalty. Therefore, his flexibility toward Jewish interests seems primarily to be due to his duties as a Roman official.

Funding: This research received no external funding.

Acknowledgments: I especially thank Chris Seeman (Walsh University) for the invitation to contribute to this special issue. Furthermore, my thanks go to Joseph Sievers (Pontifical Biblical Institute) and to James Albert Harrill (Ohio State University) for their comments on an earlier version of this article. Finally, I owe a debt of thanks also to Jay David Miller (University of Notre Dame) and Richard Peterson (University of Münster) for improving my English.

Conflicts of Interest: The author declares no conflict of interest.

\section{References}

Editions, Translations and Commentaries

Greek citations of Josephus' works are taken from Niese's Editio Maior = (Josephus 1885-95).

Josephus, Flavius. 1930; 1934; 1937; 1961; 1963; 1965. Jewish Antiquities. Translated by Louis H. Feldmann, Ralph Marcus and Allen P. Wikgren. 6 vols. Books I-VI; VII-VIII; IX-XI; XII-XIV; XV-XVII; XVIII-XX. LCL 242; 281; 326; 365; 410; 433. Josephus IV-IX. London: William Heinemann.

Josephus, Flavius. 2008. Judean War 2. Translation and Commentary by Steve Mason. Leiden and Boston: Brill.

Josephus, Flavius. 1885; 1887; 1889; 1890; 1892; 1894; 1895. Opera. Edidit et Apparatu Critico Instruxit Benedictus Niese. 7 vols. Berlin: Weidmann.

Josephus, Flavius. 1927; 1928. The Jewish War. Translated Henry St. John Thackeray. 2 vols. Books I-III; IV-VII. LCL 203; 210. Josephus II-III. London: William Heinemann.

Philo, Alexandrinus. 1960. Flaccus (In Flaccum). Edited with an Introduction and Translation by Francis Henry Colson. LCL 363. Philo IX. London: William Heinemann; Cambridge: Harvard University Press.

Philo, Alexandrinus. 1970. Philonis Alexandrini Legatio ad Gaium. $2^{\text {nd }}$ ed. Edited with an Introduction. Translation and Commentary by E. Mary Smallwood. Leiden: Brill.

$\underline{\text { Studies }}$

Bajsić, Alois. 1967. Pilatus, Jesus und Barabbas. Biblica 48: 27-8.

Bilde, Per. 1988. Flavius Josephus Between Jerusalem and Rome. His Life, His Works, and Their Importance. JPseud.S 29. Sheffield: Academic Press.

Blank, Josef. 1959. Die Verhandlung vor Pilatus Joh 18,28-19,16 im Lichte johanneischer Theologie. Biblische Zeitschrift 3: 60-81.

Blinzler, Josef. 1958. Die Niedermetzelung von Galiläern durch Pilatus. Novum Testamentum 2: 24-49.

Blinzler, Josef. 1969. Der Prozess Jesu. Das Jüdische und das Römische Gerichtsverfahren gegen Jesus Christus, $4^{\text {th }}$ ed. Regensburg: Friedrich Pustet.

Bond, Helen K. 1998. Pontius Pilate in History and Interpretation. SNTS.MS 100. Cambridge: University Press.

Bond, Helen K. 2000. The Literary function of Pontius Pilate in Josephus' narratives. In Narrativity in Biblical and Related Texts. Edited by George J. Brooke and Jean-Daniel Kaestli. BETL 149. Leuven: Peeters. pp. 213-23.

Borgen, Peder, Kåre Fuglseth, and Roald Skarsten. 1997. The Philo-Index. A Complete Greek Word Index to the Writings of Philo of Alexandria. Lemmatised and Computer-Generated. Trondheim: Religionsvitenskapelig institutt det historisk-filosofiske fakultetet. 
Davies, P. S. 1986. The Meaning of Philo's Text about the Gilded Shields. The Journal of Theological Studies 37: 10914.

Diebner, Bernd Jørg. 2002. "Pontius Pilatus" in der postkanonischen Literatur. In Jüdische Schriften in Ihrem AntikJüdischen und Urchristlichen Kontext. Edited by Hermann Lichtenberger and Gerben Oegema. JSHRZ-St 1. Gütersloh: Gütersloher Verlagshaus, pp. 429-48.

Egger, Peter. 1997. "Crucifixus sub Pontio Pilato". Das "Crimen" Jesu von Nazareth im Spannungsfeld Römischer und Jüdischer Verwaltungs- und Rechtsstrukturen. NTA 32. Münster: Aschendorff.

Fuks, Gideon. 1982. Again on the Episode of the Gilded Roman Shields at Jerusalem. Harvard Theological Review 75: 503-7.

Horn, Friedrich-Wilhelm. 2007. Das Testimonium Flavianum aus neutestamentlicher Perspektive. In Josephus und das Neue Testament. Wechselseitige Wahrnehmungen. II. Internationales Symposion zum Corpus JudaeoHellenisticum, 25.-28. Mai 2006. Edited by Christfried Böttrich and Jens Herzer. WUNT 209. Tübingen: Mohr Siebeck, pp. 117-36.

Kany, Roland. 1995. Die Frau des Pilatus und ihr Name. Zeitschrift für die neutestamentliche Wissenschaft 86: 10410.

Kertelge, Karl. 1988. Der Prozess gegen Jesus. Historische Rückfragen und theologische Deutung. Edited by Karl Kertelge. QD 112. Freiburg et al.: Herder.

Krieger, Klaus-Stefan. 1992. Die Problematik chronologischer Rekonstruktionen zur Amtszeit des Pilatus. Biblische Notizen 61: 27-32.

Krieger, Klaus-Stefan. 1994. Geschichtsschreibung als Apologetik Flavius Josephus. Tübingen: Francke.

Krieger, Klaus-Stefan. 1995. Pontius Pilatus-ein Judenfeind? Zur Problematik einer Pilatusbiographie. Biblische Notizen 78: 63-83.

Lémonon, Jean-Pierre. 2007. Ponce Pilate. First published 1981 as Pilate et le Gouvernement de la Judée. Textes et Monuments. Paris: Librairie Lecoffre et al.

Lindner, Helgo. 1972. Die Geschichtsauffassung des Flavius Josephus im Bellum Judaicum. Leiden: Brill.

Maier, Paul. 1969. The episode of the Golden Roman Shields at Jerusalem. Harvard Theological Review 62: 109-21. Malherbe, Abraham. 1986. Moral Exhortation. A Greco-Roman Sourcebook. LEC 4. Philadelphia: Westminster.

Mason, Steven. 2005. Josephus and the New Testament. $2^{\text {nd }}$ ed. Peabody: Hendrickson.

McGing, Brian. 1991. Pontius Pilate and the Sources. The Catholic Biblical Quarterly 53: 416-38.

Niemand, Christoph. 2008. Das Testimonium Flavianum. Protokolle zur Bibel 17: 45-71.

Olson, Ken A. 1999. Eusebius and the Testimonium Flavianum. The Catholic Biblical Quarterly 61: 305-22.

Schwartz, Daniel. 1983. Josephus and Philo on Pontius Pilate. The Jerusalem Cathedra 3: 26-45.

Smallwood, E. Mary. 1976. The Jews under Roman Rule. From Pompey to Diocletian. SJLA 20. Leiden: Brill.

Staats, Reinhart. 1987. Pontius Pilatus im Bekenntnis der frühen Kirche. Zeitschrift für Theologie und Kirche 84: 493-513.

Stowasser, Martin. 2008. Pontius Pilatus in der Darstellung des Bellum Iudaicum. Protokolle zur Bibel 17: 91-103. Stowers, Stanley. 1986. Letter Writing in Greco-Roman Antiquity. LEC 5. Philadelphia: Westminster.

Strobel, August. 1980. Die Stunde der Wahrheit. Untersuchungen zum Strafverfahren gegen Jesus. WUNT 21. Tübingen: Mohr Siebeck.

Thatcher, Tom. 1995. Philo on Pilate: Rhetoric or Reality? Restoration Quarterly 37: 215-8.

Tuckett, Christopher. 2000. Pilate in John 18-19. A narrative-critical approach. In Narrativity in Biblical and Related Texts. Edited by George J. Brooke and Jean-Daniel Kaestli. BETL 149. Leuven: Peeters, pp. 131-58.

Whealey, Alice. 2007. Josephus, Eusebius of Caesarea, and the Testimonium Flavianum. In Josephus und das Neue Testament. Wechselseitige Wahrnehmungen. II. Internationales Symposion zum Corpus Judaeo-Hellenisticum, 25.-28. Mai 2006. Edited by Christfried Böttrich and Jens Herzer. WUNT 209. Tübingen: Mohr Siebeck, pp. 73-116.

Zeitlin, Solomon. 1965. Did Agrippa write a letter to Gaius Caligula? The Jewish Quarterly Review 56: $22-31$.

(C) 2020 by the author. Licensee MDPI, Basel, Switzerland. This article is an open access article distributed under the terms and conditions of the Creative Commons Attribution (CC BY) license (http://creativecommons.org/licenses/by/4.0/). 